\title{
Improvement of OMI ozone profile retrievals in the upper troposphere and lower stratosphere by the use of a tropopause-based ozone profile climatology
}

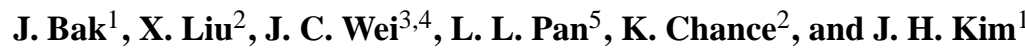 \\ ${ }^{1}$ Pusan National University, Busan, Korea \\ ${ }^{2}$ Harvard-Smithsonian Center for Astrophysics, Cambridge, MA, USA \\ ${ }^{3}$ Adnet Systems, Inc., Rockville, MD, USA \\ ${ }^{4}$ NASA Goddard Space Flight Center, Greenbelt, MD, USA \\ ${ }^{5}$ National Center for Atmospheric Research, Boulder, CO, USA \\ Correspondence to: J. H. Kim (jaekim@pusan.ac.kr)
}

Received: 21 November 2012 - Published in Atmos. Meas. Tech. Discuss.: 14 May 2013

Revised: 17 July 2013 - Accepted: 22 July 2013 - Published: 3 September 2013

\begin{abstract}
Motivated by the need of obtaining a more accurate global ozone distribution in the upper troposphere and lower stratosphere (UTLS), we have investigated the use of a tropopause-based (TB) ozone climatology in ozone profile retrieval from the Ozone Monitoring Instrument (OMI). Due to the limited vertical ozone information in the UTLS region from OMI backscattered ultraviolet radiances, better climatological a priori information is important for improving ozone profile retrievals. We present the new TB climatology and evaluate the result of retrievals against previous work. The TB climatology is created using ozonesonde profiles from 1983 through 2008 extended with climatological ozone data above sonde burst altitude $(\sim 35 \mathrm{~km})$ with the corresponding temperature profiles used to identify the thermal tropopause. The TB climatology consists of the mean states and $1 \sigma$ standard deviations for every month for each $10^{\circ}$ latitude band. Compared to the previous TB climatology by Wei et al. (2010), three additional processes are applied in deriving our climatology: (1) using a variable shifting offset to define the TB coordinate, (2) separating ozonesonde profiles into tropical and extratropical regimes based on a threshold of $14 \mathrm{~km}$ in the thermal tropopause height, and (3) merging with an existing climatology from $5-10 \mathrm{~km}$ above the tropopause. The first process changes the reference of profiles to a variable position between local and mean tropopause heights within $\pm 5 \mathrm{~km}$ of the tropopause and to the mean tropopause elsewhere. The second helps
\end{abstract}

to preserve characteristics of either tropical or extratropical ozone structures depending on tropopause height, especially in the subtropical region. The third improves the climatology above ozonesonde burst altitudes and in the stratosphere by using climatology derived from many more satellite observations of ozone profiles. With aid from the National Centers for Environmental Prediction (NCEP) Global Forecast System (GFS) tropopause height, the new climatology and retrieval can better represent the dynamical variability of ozone in the tropopause region. The new retrieval result demonstrates significant improvement of UTLS ozone, especially in the extratropical UTLS, when evaluated using ozonesonde measurements and the meteorological data. The use of TB climatology significantly enhances the spatial consistency and the statistical relationship between ozone and potential vorticity/tropopause height in the extratropical UTLS region. Comparisons with ozonesonde measurements show substantial improvements in both mean biases and their standard deviations over the extratropical lowermost stratosphere and upper troposphere. Overall, OMI retrievals with the TB climatology show improved ability in capturing ozone gradients across the tropopause found in tropical/extratropical ozonesonde measurements. 


\section{Introduction}

Ozone distribution and variability in the upper troposphere (UT) and lower stratosphere (LS) has a significant role in chemistry-climate interaction. Increasing greenhouse gases tend to warm the troposphere but cool the stratosphere, contributing to the rise of the tropopause and hence the increase of the stratospheric ozone depletion (Steinbrecht et al., 1998; de Forster and Tourpali, 2001; Santer et al., 2004). The change in the stratospheric ozone budget directly affects the temperature structure in both the stratosphere and troposphere, which then can alter the tropospheric weather system (de Forster and Shine, 1997). Synoptic-scale weather disturbances in the troposphere are closely coupled to shortterm variations in stratospheric ozone (Hegglin et al., 2008). The stratosphere-troposphere exchange in the extratropical UTLS plays an important role in the ozone budget and radiance balance in the upper troposphere (Holton et al., 1995). Dynamical processes such as tropopause folding, upper tropospheric frontal layer, double tropopause and associated tropospheric intrusions are important for UTLS ozone budget and variability (Langford, 1999; Randel et al., 2007; Pan et al., 2004; Pan and Munchak, 2011).

Research efforts for quantifying UTLS processes have mostly used high resolution in situ measurements by radiosonde, ozonesonde and aircraft, although satellite observations are required in order to establish a global climatology. Space-borne nadir-viewing backscattered ultraviolet (BUV) instruments often have difficulty in resolving the sharp gradient of ozone across the tropopause due to the coarse vertical resolution derived from the measurements, which motivates this work to investigate how to improve the ability of ozone profile retrieval to better represent the UTLS ozone structure.

Satellite-based observation of ozone profiles/total ozone from nadir-viewing BUV radiances has been routinely performed since 1978 with Solar Backscattered Ultraviolet (SBUV) and SBUV-2 instruments flown on National Aeronautics and Space Administration (NASA) and the National Oceanic and Atmospheric Administration (NOAA) satellites (McPeters et al., 1984). Because these instruments measure BUV radiances only at 12 discrete wavelength bands in the range of 256-340 nm, the information on ozone vertical distribution is limited to $20-50 \mathrm{~km}$ (Bhartia et al., 1996). With the launch of UV/visible spectrometers such as the Global Ozone Monitoring Experiment (GOME) (ESA, 1995), which take BUV radiance spectra at moderate spectral resolution, the retrieval of vertical ozone profiles can be extended down to the troposphere (Chance et al., 1997; Meijer et al., 2006 and references therein).

Liu et al. (2005) developed an optimal estimation (OE)based algorithm to retrieve ozone profiles including tropospheric ozone from GOME BUV radiance spectra. They demonstrated that the weak tropospheric ozone information can be extracted from the GOME measurements by improving the wavelength/radiometric calibrations and forward modeling simulations, reducing fitting residuals in the Huggins bands to $0.1-0.2 \%$. This algorithm has also been successfully applied to BUV radiances measured by the Ozone Monitoring Instrument (OMI) (Liu et al., 2010a,b). Because of the ill-posed nature of ozone profile retrievals, it uses a latitudinal and monthly dependent climatology (including both means and standard deviations) (McPeters et al., 2007) as a prior constraint to regularize and stabilize the retrievals, together with the measurement error constraint.

The ability of OMI to capture the dynamic variability of ozone and large gradients across the tropopause is limited compared to high vertical resolution in situ measurements. Unlike limb-viewing measurements such as Microwave Limb Sounder (MLS), the vertical resolution of OMI measurements is rather coarse, $6-10 \mathrm{~km}$ in the stratosphere and $10-15 \mathrm{~km}$ in the troposphere, as determined in Liu et al. (2010a). As shown in several validation studies for OMI ozone profile retrievals, there are significant biases in the OMI ozone compared to high resolution in situ measurements in the tropopause region. As examples, Pittman et al. (2009) compared OMI retrievals with in situ aircraft measurements and meteorological data. Their comparison demonstrated the capability of OMI observations to capture large-scale ozone gradients associated with the strong gradients of potential vorticity but the limited capability to reproduce the sharpness of ozone gradients near the tropopause captured in the aircraft measurements. Liu et al. (2010b) demonstrated the major contribution of the OMI smoothing errors (resulting from the limited vertical resolution and the use of climatological a priori) to large differences between OMI and MLS ozone profiles around $100 \mathrm{hPa}$. Therefore, some of the large biases in the UTLS might originate from the mismatch between the actual ozone profile and the a priori ozone profile. The current a priori in retrieving ozone profiles is taken from the monthly and zonal mean ozone profile climatology and that is inadequate to represent the dynamic variability of ozone. This study examines the use of climatological a priori information as a function of a dynamics indicator to improve ozone retrievals. The tropopause height is an excellent indicator for selecting the shape of the ozone profile containing the dynamics. A strong negative correlation between total ozone and tropopause height has been a well-known feature (e.g., Steinbrecht et al., 1998). The daily change in the height of the tropopause accounts for $\sim 60 \%$ of the large variability in the total ozone (Wei et al., 2010). The tropopause-reference coordinate is an established method to remove the variability induced by the variance of tropopause heights (Logan, 1999; Pan et al., 2004, 2007; Birner, 2006; Considine et al., 2008; Hegglin et al., 2008, 2009; Wei et al., 2010). A recent study by Wei et al. (2010) (hereafter Wei2010) constructed an ozone profile climatology (Tropopause-based, "TB”, climatology) from the $24 \mathrm{yr}$ (1983-2008) of ozonesonde data using a TB coordinate and applied it to ozone profile retrievals from the 
Atmospheric Infrared Sounder (AIRS). The improvements of the retrievals using the TB climatology included better preserving the shape and magnitude of the ozone gradient near the tropopause.

The main goal of this study is to examine OMI ozone profile retrievals in the tropopause region with the TB climatology. We adapt and improve the Wei2010 TB climatology for our retrieval algorithm. We explore the impact of using TB a priori on the performance of OMI retrievals with respect to meteorological variables derived from the National Centers for Environmental Prediction (NCEP) Global Forecast System (GFS) model and four years (2004-2008) of ozonesonde measurements at six stations. The UTLS horizontal and vertical variability of the OMI retrievals/a priori is compared with the dynamical behaviors captured from GFS potential vorticity and thermal tropopause height fields. We include statistical comparisons between OMI retrievals and ozonesonde measurements. The ability of OMI retrievals to capture the cross-tropopause ozone gradients seen by ozonesonde observations is validated. This paper is organized as follows: Sect. 2 gives a brief description of the OMI and ozone profile retrievals. Our new TB ozone climatology is introduced in Sect. 3. The retrievals based on the different a priori are evaluated with respect to meteorological data in Sect. 4 and ozonesonde data in Sect. 5. Section 6 summarizes this study.

\section{OMI and OMI ozone profile retrievals}

OMI, on board the Aura satellite launched in July 2004, is a nadir UV/visible instrument that measures backscattered radiances in the wavelength range of 270-500 nm (UV-1: 270$310 \mathrm{~nm}, \mathrm{UV}-2$ : $310-365 \mathrm{~nm}$, visible: $350-500 \mathrm{~nm}$ ) at spectral resolution of $0.42-0.63 \mathrm{~nm}$ (Levelt et al., 2006). It provides daily global coverage. The nadir spatial resolution is $13 \mathrm{~km} \times 24 \mathrm{~km}$ (along $\times$ across track) for UV-2 and visible channels and $13 \mathrm{~km} \times 48 \mathrm{~km}$ for UV-1, increasing substantially at larger viewing angles.

We used the OMI ozone profile retrieval algorithm of Liu et al. (2010a), which is based on the optimal estimation technique (Rodgers, 2000). This retrieval scheme approaches an optimal solution by simultaneously and iteratively minimizing the differences between measured and simulated radiances and between retrieved and a priori state vectors, constrained by measurement error and a priori covariance matrices. The a priori state and its covariance matrix were defined from the Labow-Logan-McPeters (LLM) ozone climatology, consisting of monthly averaged ozone profiles and their standard deviations from $1810^{\circ}$-latitude bands (McPeters et al., 2007). This LLM ozone climatology was compiled from ozonesonde data (1988-2001) for the troposphere and lower stratosphere and from Stratospheric Aerosol and Gas Experiment 2 (SAGE 2; 1988-2002) and Upper Atmospheric Research Satellite (UARS) MLS (19911999) data for the stratosphere. The merge altitude range is $10-18 \mathrm{~km}$ for SAGE2 and sonde measurements and 20 $28 \mathrm{~km}$ for MLS and sonde measurements.

In this OMI algorithm, the profile of partial ozone columns in Dobson Unit (DU) is retrieved at 24 layers from the surface to $\sim 60 \mathrm{~km}(\sim 2.5 \mathrm{~km}$ thickness per layer) from BUV radiances in the spectral region of $270-330 \mathrm{~nm}$ (Liu et al., 2010a). The tropopause height is used as one retrieval level to separate the stratosphere and troposphere; tropospheric and stratospheric ozone columns are integrated from the retrieved ozone profiles. The retrieved ozone profiles have 4 to 7 layers in the troposphere, depending on the latitude. The spatial resolution of our retrievals equals that of UV-1 measurements. The vertical resolution, estimated by Liu et al. (2010a), varies from $7-11 \mathrm{~km}$ in the stratosphere and $10-14 \mathrm{~km}$ in the troposphere. The retrieval errors (defined as the root sum square of precisions and smoothing errors) range from $1-6 \%$ in the stratosphere to 6-35\% in the troposphere.

\section{Tropopause-based (TB) ozone climatology}

We use the same dataset used in Wei2010 to derive the TB climatology, consisting of the global ozonesonde ozone/temperature profiles from 1983 to 2008, which are collected from the World Ozone and Ultraviolet Data Center (WOUDC), the Southern Hemisphere Additional Ozonesondes (SHADOZ) network and the NOAA Earth System Research Laboratory (ESRL) Global Monitoring Division (GMD). 51736 sonde profiles are used, compared to 23,400 for the LLM climatology. Global coverage is greatly improved compared to the 36 stations used to derive the LLM climatology (compare Fig. 3 in Wei2010 and Table 1 in McPeters et al., 2007). The ozonesonde profiles are extended with existing climatology above sonde burst altitude ( $\sim 35 \mathrm{~km}$ ) up to $0.005 \mathrm{hPa}$ and then are interpolated into 100 vertical layers (e.g., an $\sim 0.5 \mathrm{~km}$ grid in the UT/LS). The individual temperature profile from each ozonesonde was used to determine the height of the lapse-rate tropopause (called "thermal tropopause") using the World Meteorological Organization (WMO) definition (WMO, 1957); thermal tropopause is the lowest level at which the lapse rate decreases to $2{ }^{\circ} \mathrm{C} \mathrm{km}^{-1}$ or less, provided also the average lapse rate between this level and all higher levels within $2 \mathrm{~km}$ does not exceed $2{ }^{\circ} \mathrm{C} \mathrm{km}^{-1}$.

The TB coordinate is generally defined as the altitudebased (AB) coordinate minus the location and time dependent tropopause height, i.e., "zero $\mathrm{km}$ " is set to be the tropopause level in the TB coordinate, whereas it is set to be the surface level in the $\mathrm{AB}$ coordinate. The monthly averages and their $1 \sigma$ standard deviations were calculated in $1810^{\circ}$-latitude bins using the ozone profiles relative to the tropopause and surface, respectively; the former is called "TB climatology" and the latter is called "AB climatology". The TB climatology covers from $20 \mathrm{~km}$ below the tropopause to $60 \mathrm{~km}$ above the tropopause for every $\mathrm{km}$ and the $\mathrm{AB}$ 
Table 1. List of ozonesonde stations.

\begin{tabular}{lrrlcl}
\hline Station & Lat., deg & Lon., deg & Type $^{\mathrm{a}}$ & $\begin{array}{r}\text { Number of } \\
\text { coll. }\end{array}$ & Data archive $^{\mathrm{c}}$ \\
\hline Sodankylä & 67.39 & 26.65 & ECC & 189 & WOUDC \\
Hohenpeißenberg & 47.8 & 11.02 & BM & 415 & WOUDC \\
Wallop Island & 37.9 & -75.7 & ECC & 184 & WOUDC \\
Hilo & 19.43 & -155.04 & ECC & 141 & CMDL \\
Nairobi & -1.27 & 36.8 & ECC & 109 & SHADOZ \\
Ascension Island & -7.98 & -14.42 & ECC & 143 & SHADOZ \\
\hline
\end{tabular}

${ }^{a}$ Ozonesonde types: Electrochemical cell (ECC) and Brewer-Mast (BM). ${ }^{b}$ Number of collocated profiles between OMI and sonde during the period 2004 to 2008. ${ }^{\mathrm{c}}$ Data are downloaded from the WOUDC

(http://www.woudc.org) data archive, except for Nairobi and Ascension Island, which are from the SHADOZ data archive (http://croc.gsfc.nasa.gov/shadoz), and Hilo, which is from the NOAA Climate Monitoring Diagnostics Laboratory (CMDL) data archive (http://www.cmdl.noaa.gov/infodata/ftpdata.html).
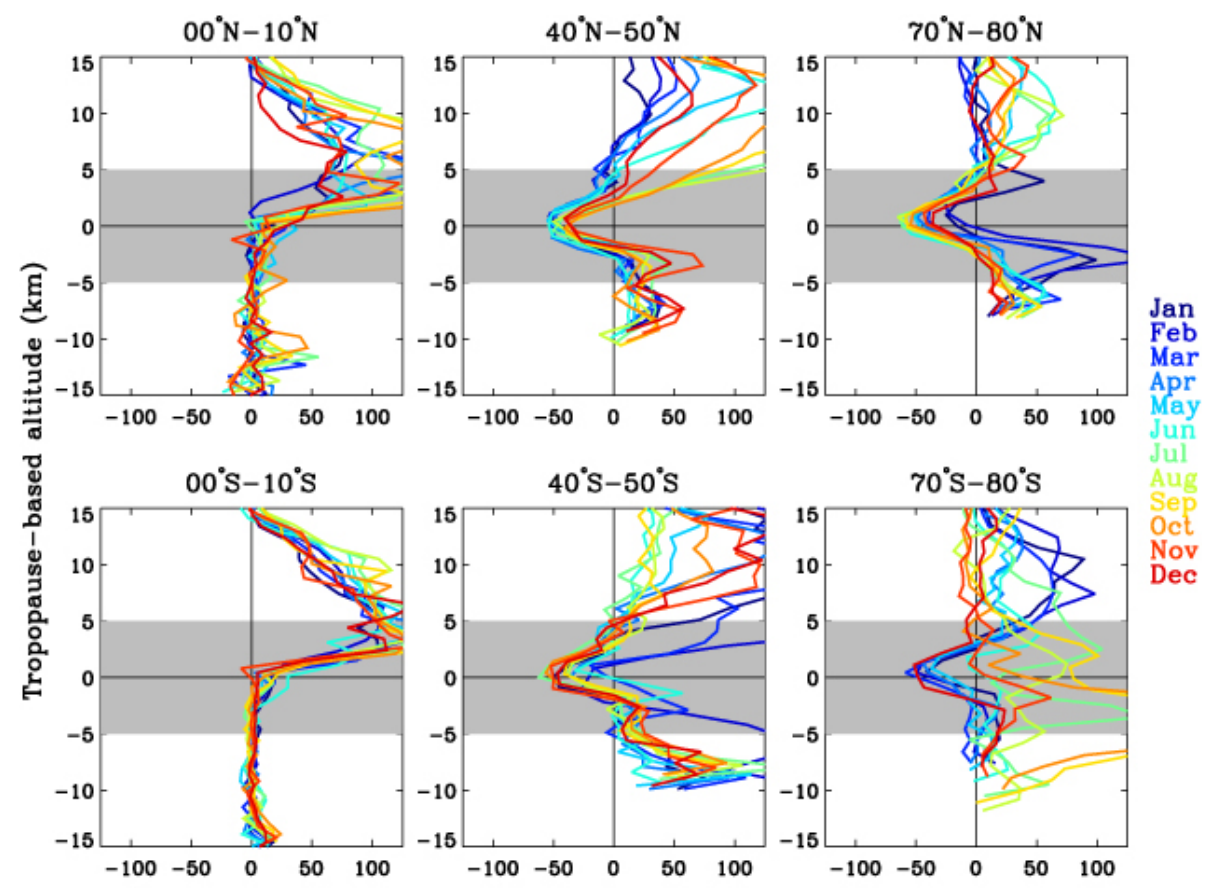

Difference in $1^{\circ}$ standard deviations between $\mathrm{TB}$ and $\mathrm{AB}(\%)$

Fig. 1. Relative difference in $1 \sigma$ standard deviations between tropopause-based (TB) and altitude-based (AB) climatologies as a function of altitude relative to the corresponding mean tropopause for 12 months at tropical $\left( \pm 5^{\circ}\right)$, middle $\left( \pm 45^{\circ}\right)$, and high $\left( \pm 75^{\circ}\right)$ latitudinal bands. The relative difference is defined as $(\mathrm{TB}-\mathrm{AB}) / \mathrm{AB} \times 100 \%$.

climatology covers from the surface to $60 \mathrm{~km}$ for every $\mathrm{km}$. For the TB climatology, unavailable ozone values at altitudes below surface are filled with surface values.

We examine how much the climatological variabilities of ozone profiles decrease due to the change from $\mathrm{AB}$ to $\mathrm{TB}$ coordinates. Figure 1 shows the relative differences in $1 \sigma$ standard deviations between TB and AB ozone climatologies with the altitude relative to the tropopause at selected latitude bands for all months. For comparison, the vertical coordinate of AB climatology is adjusted into the TB coordinate using the corresponding mean tropopause height. Note that both climatologies used in this comparison are made almost in the same manner as in Wei2011. The use of the TB coordinate effectively reduces the climatological variability by up to $\sim 50 \%$ within a few kilometers $(\mathrm{km})$ around the tropopause in the extratropical regions for all seasons with some exceptions in the southern high latitudes. The reduction in ozone variability due to use of the TB coordinate appears to be larger at $\mathrm{mid} / \mathrm{high}$ latitudes of the Northern Hemisphere than at those of the Southern Hemisphere. This may be because the Northern Hemisphere has a stronger dynamical environment. The standard deviations of ozone profiles in the 
$\mathrm{TB}$ coordinate become larger than those in the $\mathrm{AB}$ coordinate beyond a certain distance from the extratropical tropopause by up to more than $100 \%$. For tropical bands, the TB climatology shows much larger variability even just above the tropopause compared to the $\mathrm{AB}$ climatology. To conclude, there are limitations in applying this TB climatology everywhere. The remainder of this section will describe the way in which we improve the TB climatology considering the limitations given above.

Firstly, from Fig. 1, the advantage of using the TB coordinate in better representing the climatological ozone variability is confined to within a few $\mathrm{km}$ around the tropopause. Therefore, we construct our climatology in such a way that ozone profiles smoothly change from $\mathrm{TB}$ means to $\mathrm{AB}$ means until the distance is beyond $5 \mathrm{~km}$ from the tropopause. This is accomplished using a variable shifting offset in mapping the altitude to the TB coordinate as follows:

$Z_{\mathrm{tb}}=Z_{\mathrm{ab}}-Z_{\mathrm{offset}}$,

where

$$
Z_{\text {offset }}= \begin{cases}\left(h_{\mathrm{tp}}-\overline{h_{\mathrm{tp}}}\right) \times\left(1-\frac{\left|Z_{\mathrm{ab}}-h_{\mathrm{tp}}\right|}{5}\right)+\overline{h_{\mathrm{tp}}} & \text { if }\left(\left|Z_{\mathrm{ab}}-h_{\mathrm{tp}}\right|<5 \mathrm{~km}\right) \\ h_{\mathrm{tp}} & \text { if }\left(\left|Z_{\mathrm{ab}}-h_{\mathrm{tp}}\right| \geq 5 \mathrm{~km}\right)\end{cases}
$$

$Z_{\mathrm{tb}}$ and $Z_{\mathrm{ab}}$ denote the altitudes defined by the TB and $\mathrm{AB}$ coordinates, respectively. $\overline{h_{\mathrm{tb}}}$ and $h_{\mathrm{tp}}$ are the monthly zonal mean and local tropopause heights, respectively. When $\overline{h_{\mathrm{tb}}} \neq h_{\mathrm{tp}}$, the mapping of an ozone profile is a uniform shift between $\mathrm{TB}$ and $\mathrm{AB}$ coordinates without altering the spacing of the sample points. Otherwise, when $\overline{h_{\mathrm{tb}}}<h_{\mathrm{tp}}\left(\overline{h_{\mathrm{tb}}}>h_{\mathrm{tp}}\right)$, an ozone profile is slightly squeezed below (above) and stretched above (below) when mapped into the TB coordinate. The variable offset term $Z_{\text {offset }}$ varies with the distance from the tropopause height $\left(\left|Z_{\mathrm{ab}}-h_{\mathrm{tp}}\right|\right)$, whereas the traditional offset term is defined as $h_{\text {tp }}$ regardless of altitude. $Z_{\text {offset }}$ is weighted linearly, from $100 \% h_{\mathrm{tp}}$ at the tropopause to $100 \% \overline{h_{\mathrm{tp}}}$ at $5 \mathrm{~km}$ away from the tropopause, which essentially results in the weighted average between tropopauseand altitude-based ozone profiles in this range. At altitudes beyond $5 \mathrm{~km}$ above/below the tropopause, it is fixed to $\overline{h_{\mathrm{tb}}}$, which results in profiles similar to altitude-based ozone profiles. It should be noted that the use of a variable offset is used only in the construction of the climatology. In the retrieval algorithm, the vertical coordinate of TB climatology is adjusted to the $\mathrm{AB}$ coordinate using the constant shifting offset.

Secondly, we separate the ozonesonde profiles into tropical and extratropical groups in order to remove ozone variability caused by the mixing of tropical and extratropical air masses, especially in the subtropics. The separation of the tropical and extratropical air masses based on the height of the tropopause was emphasized for obtaining the distinct characteristics in the climate change, trace gas, and dynamics process for each over the subtropical region (Pan et al., 2004; Tilmes et al., 2010; Pan and Munchak, 2011). A threshold

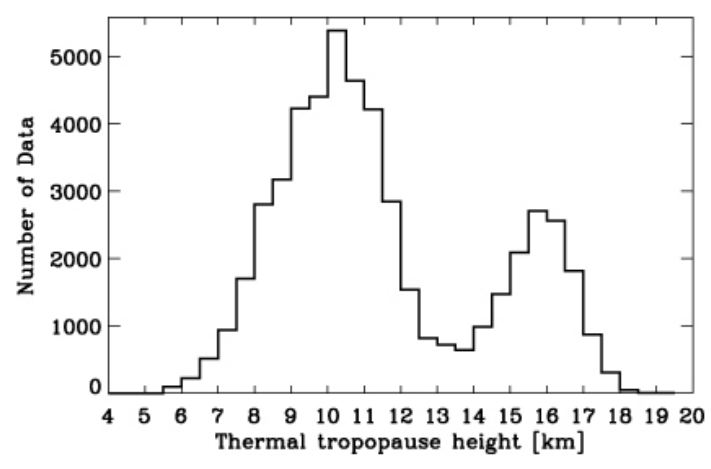

Fig. 2. Histogram of thermal tropopause heights collected from global ozonesonde soundings from 1983 to 2008. The WMO definition (1957) is applied to determine the thermal tropopause height.

of the thermal tropopause height can be used for this purpose. A number of previous studies have chosen threshold values between 13 and $15 \mathrm{~km}(\sim 135 \mathrm{hPa})$, corresponding to the lowest frequency between the two peaks in the bimodal distribution of the tropopause height for the global or the subtropical region (Hoinka, 1997; Pan et al., 2004; Birner, 2010; Homeyer et al., 2010; Pan and Munchak, 2011). Figure 2 displays the frequency distribution of the thermal tropopause heights collected from all stations used in this study. Because the lowest frequency between the two peaks occurs at 13.5$14 \mathrm{~km}$, we choose the closest whole number, $14 \mathrm{~km}$, as the threshold value in this study. The extratropical TB climatology was derived in the TB coordinate using ozonesonde profiles with a tropopause height $\leq 14 \mathrm{~km}$, derived for latitude bands above $35^{\circ} \mathrm{N} / \mathrm{S}$. Although the use of the TB coordinate in the tropical tropopause leads to larger standard deviations above the tropopause (Fig. 1), the use of the tropical AB climatology together with the use of the extratropical TB climatology causes some discontinuity in the subtropical region. The larger standard deviations of the tropical TB climatology above the tropopause do not adversely affect OMI retrievals in the tropics, as indicated in Sect. 5. Therefore, we decided to use the TB coordinate in deriving the tropical climatology. Similarly, the tropical TB climatology was derived using profiles with a tropopause height $>14 \mathrm{~km}$ and could be derived for latitude bands below $25^{\circ} \mathrm{S}$ and $35^{\circ} \mathrm{N}$ for the southern and northern tropical regions, respectively. However, for deriving the $\mathrm{AB}$ climatology (used as retrieval comparison in this study), we still used all sonde profiles without additional tropopause constraint.

Finally, the improved version of the TB climatology is presented in Fig. 3 in the same way as in Fig. 1. The tropical TB climatology shows a great reduction in climatological errors compared to the original TB climatology, but still shows more variability compared to the $\mathrm{AB}$ climatology within 5 $\mathrm{km}$ above the tropopause. The reduction of climatological variabilities shown in the extratropical TB climatology for \pm 45 and $\pm 75^{\circ}$ maximizes at the tropopause ( $\left.0 \mathrm{~km}\right)$ by up to 

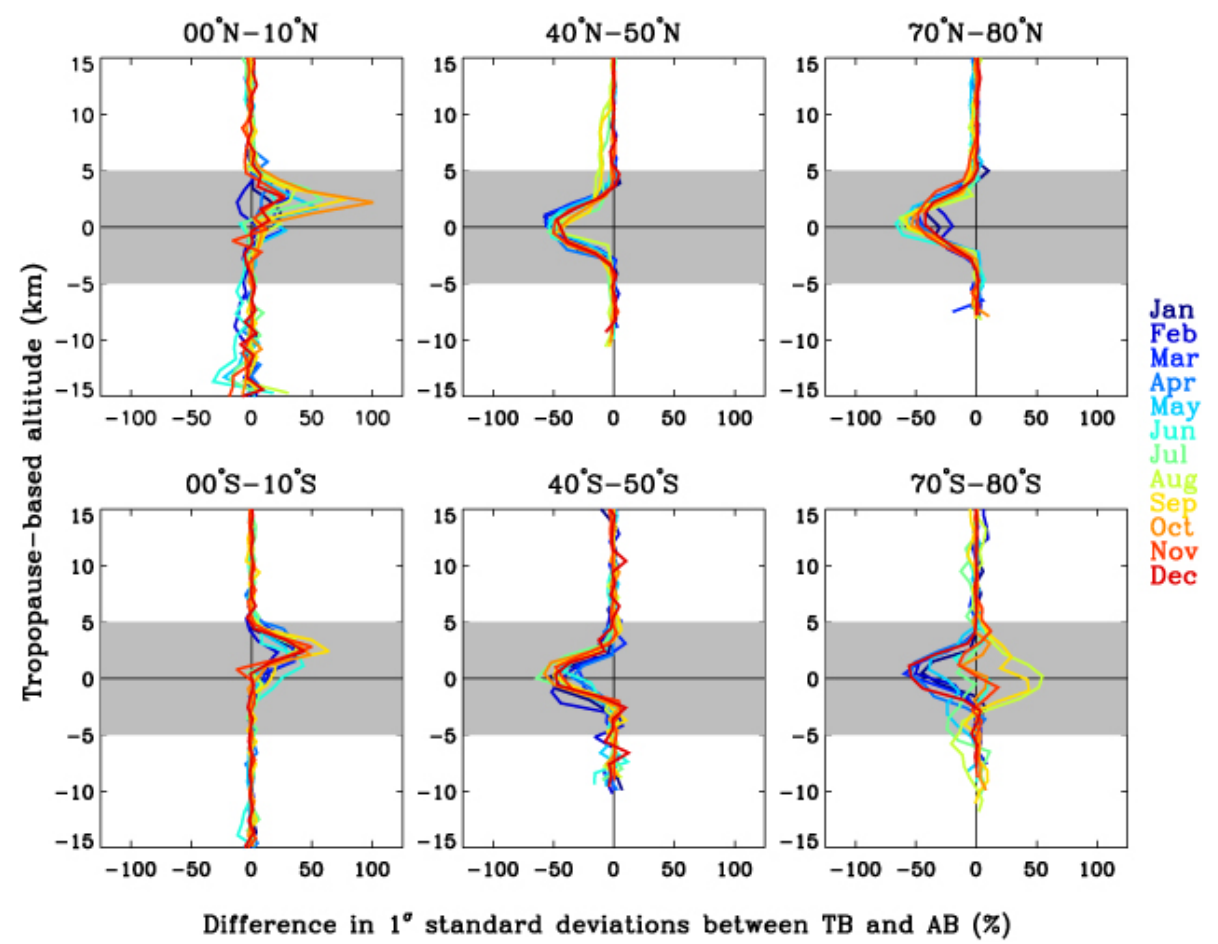

Fig. 3. Same as Fig. 1, but for the improved version of the TB climatology. The TB climatology is derived using sonde profiles with tropopause height greater than $14 \mathrm{~km}$ for $\pm 5^{\circ}$ and with tropopause height less than $14 \mathrm{~km}$ for \pm 45 and $\pm 75^{\circ}$. The TB coordinate is defined using the variable shifting offset through Eqs. (1) and (2).

$\sim 50 \%$, then gradually decreases to nearly zero from 0 to $\pm 5 \mathrm{~km}$, with the variable offset being weighted toward $\overline{h_{\mathrm{tp}}}$, and then remains nearly marginal with the variable offset being fixed to $\overline{h_{\mathrm{tp}}}$. The magnitude of reduction does not vary much with either season or latitude compared to the TB coordinate with the constant shifting offset.

Due to the appending of climatological ozone profiles with individual ozonesonde profiles above sonde burst altitude, the standard deviations above $\sim 40 \mathrm{~km}$ from the $\mathrm{AB} /$ modified TB climatology are very small, as expected, and cannot represent the actual climatological variability. This does not pose a big problem for AIRS retrievals, as the vertical information is very weak in the middle and upper stratosphere. However, such a small a priori constraint would be too tight for OMI retrievals, as there is a relatively significant amount of vertical information at such altitudes. In addition, many more stratospheric ozone profiles from SAGE 2 and MLS are used in deriving the LLM climatology than the number of ozonesonde profiles used in deriving the TB/AB climatology. Therefore, we decided to merge AB/TB climatologies with the LLM climatology from 5 to $10 \mathrm{~km}$ above the tropopause and completely replace them with the LLM climatology for altitudes above that.

In the retrieval algorithm, the TB ozone profile is vertically adjusted with the TB coordinate plus the local tropopause height (constant shifting offset). The local tropopause is obtained from NCEP GFS tropopause height $\left(1.0^{\circ}\right.$ longitude $\times 1.0^{\circ}$ latitude), which allows the TB a priori to represent the daily horizontal and vertical variability of ozone in the UTLS. The extratropical TB ozone profile is used as the a priori if the tropopause height is $\leq 13 \mathrm{~km}$ and the tropical TB ozone profile is used if the tropopause height is $\geq 15 \mathrm{~km}$. In case either extratropical or tropical TB climatology is not available, we use the profile from the closest latitude band (e.g., the extratropical TB profile of $35^{\circ} \mathrm{N}$ is used at $20^{\circ} \mathrm{N}$ where the tropopause height is $\leq 13 \mathrm{~km}$ ). In the transition zone between 13 and $15 \mathrm{~km}$, the a priori is weighted linearly from $100 \%$ extratropical TB profile at $13 \mathrm{~km}$ to $100 \%$ tropical TB profile at $15 \mathrm{~km}$. Similarly, we derive the a priori error for ozone profile retrievals from the standard deviations of the TB climatology.

We will show the improvement of ozone profile retrievals using the $\mathrm{TB}$ climatology over other $\mathrm{AB}$ climatologies in Sects. 4 and 5. It should be noted that the improvement comes from the better a priori knowledge only, and using the TB climatology does not facilitate the extraction of more information from the measurements. The switch of climatologies has negligible effects on the fitting residuals. In addition, switching from $\mathrm{AB}$ climatology to the $\mathrm{TB}$ climatology only slightly changes the retrieval sensitivities, as represented by retrieval averaging kernels (AKs). We compared the diagonal elements of OMI AKs, generally called "degrees of freedom for signal" (DFS), at each layer. Due to smaller TB a priori errors around the extratropical tropopause, the DFS values 
are smaller by $\sim 0.1$ on average with the use of TB a priori than with the use of other a priori around the extratropical tropopause. The changes at other altitude ranges and in the tropics are very small.

\section{Comparison with meteorological data}

To evaluate the ozone profile retrieval in the UTLS region, the consistency of ozone distribution with the meteorological fields is an important diagnostic. In this section, we examine the dynamical variability of retrieved UTLS ozone using the two different climatologies (TB, LLM). The meteorological variables involved in this analysis, the thermal tropopause, potential vorticity, and winds, are from the NCEP GFS model as part of the final operational global analysis. The model run is documented online (http://www.emc.ncep.noaa.gov/ modelinfo/index.html). The data we use are maintained and provided by the Computational and Informational Systems Laboratory (CISL) of NCAR (http://rda.ucar.edu/datasets/ ds083.2/) and are produced on $1^{\circ} \times 1^{\circ}$ grids at 26 pressure levels ranging from $10-1000 \mathrm{hPa}$ at four times daily (00:00, 06:00, 12:00, 18:00 UTC). For a better comparison with OMI retrievals, the GFS fields are linearly interpolated into OMI overpass time of 13:45 LT (local time) at the equator. Retrieved partial ozone columns at 24 layers are interpolated to a finer 100-layer vertical grid and then converted to a volume mixing ratio (ppbv). Section 4.1 examines the horizontal and vertical variability in the ozone retrievals and their a priori. Section 4.2 discusses the correlation between ozone and potential vorticity.

\subsection{Dynamical variability of UTLS ozone}

Figure $4 \mathrm{a}$ and $\mathrm{b}$ show the horizontal distributions of a priori state from the TB and LLM ozone climatologies at 212 and $300 \mathrm{hPa}$ over Europe on 10 April 2007. The GFS potential vorticities (PV) at the corresponding pressure levels and tropopause heights are also presented in Fig. $4 \mathrm{c}$ and d. The potential vorticity is expressed in PVU (Potential Vorticity Unit: $1.0 \times 0^{-6} \mathrm{~km}^{2} \mathrm{~kg}^{-1} \mathrm{~s}^{-1}$ ). The LLM climatology only captures the latitudinal variability from lower ozone at lower latitudes to higher ozone at higher latitudes. On the other hand, the TB climatology captures well the large synopticscale ozone gradients at the mid/high latitudes that are highly consistent with the gradients in the tropopause height and the PV data. The high ozone values in TB climatology are closely collocated with the low tropopause heights and high $\mathrm{PV}$ values, illustrating the characteristics of the stratosphere. Both OMI ozone fields retrieved using TB and LLM a priori in Fig. 5 show the large-scale ozone features associated with the dynamics process. However, the TB retrievals much better preserve the ozone gradient associated with dynamic processes and show cleaner separation of ozone from different air masses.
Figure $6 \mathrm{a}$ and $\mathrm{b}$ compare the vertical structures of the retrievals/a priori with the use of the LLM and TB climatologies along the orbital track shown in Figs. 4d and 6c, and d compares the associated errors. The contours of high wind speed (black dotted lines) mark the two jet cores, located at $\sim 20^{\circ} \mathrm{N}$ near $200 \mathrm{hPa}$ and at $\sim 45^{\circ} \mathrm{N}$ near $250 \mathrm{hPa}$. The chemical and dynamical tropopause heights that separate the air masses into the stratosphere and troposphere are plotted in the same figure, to be compared with the variation of ozone structures. Typically, the ozone values less than $100 \mathrm{ppbv}$ are associated with tropospheric air and the ozone values greater than $300 \mathrm{ppbv}$ are associated with the stratospheric air (Pan et al., 2004; Varotsos et al., 2004; Kunz et al., 2011). The ozone values between 100 and $300 \mathrm{ppbv}$ represent the chemical transition from the stratosphere to troposphere. It is shown that the thermal tropopause (black line with circle) generally lies within the transition zone between 100 and 200 ppbv for both retrievals at mid/high latitudes. We choose the $125 \mathrm{ppbv}$ as the chemical boundary (black line with $\mathrm{X}$ ) to be compared. The value of $2 \mathrm{PVU}$ is used to indicate the dynamical boundary (white line), which has been used commonly to identify the stratospheric air in the upper troposphere (e.g., Holton et al., 1995; Pan et al., 2004; Pittman et al., 2009; Wei et al., 2010).

Both retrievals well represent the overall rapid ozone change with respect to latitude at the north sides of the two jet streams. In detail, however, these two retrievals reproduce different ozone behaviors. The ozone tropopause from the TB a priori/retrievals tracks the thermal and dynamic tropopause much better than does that from the LLM retrievals. The use of the LLM a priori leads to large discrepancies between thermal and chemical tropopause heights, especially between $25-45^{\circ} \mathrm{N}$, and large fluctuations of the retrievals around the tropopause at latitudes above $50^{\circ} \mathrm{N}$. The LLM retrievals sometimes show stronger penetrations of high stratospheric ozone into the upper troposphere (i.e., below the dynamic tropopause) at middle and high latitudes, indicating too much smoothing from the stratosphere to the troposphere in the retrievals. In addition, retrieval errors in the extratropical tropopause region are considerably reduced by using the newly-developed TB climatology, resulting from the reduced variance in the a priori constraint. TB retrievals/a priori also show much smaller errors in the tropical upper troposphere, which is likely due to the reduced climatological variability resulting from the use of more ozonesonde stations and more data in developing this TB climatology. The high consistency between chemically and dynamically defined tropopause surfaces and the significantly reduced retrieval errors around the extratropical tropopause when using the TB a priori indicate the potential of using the OMI ozone profile for characterizing the global features of chemical transition layers associated with the dynamical processes. 
(a) LLM

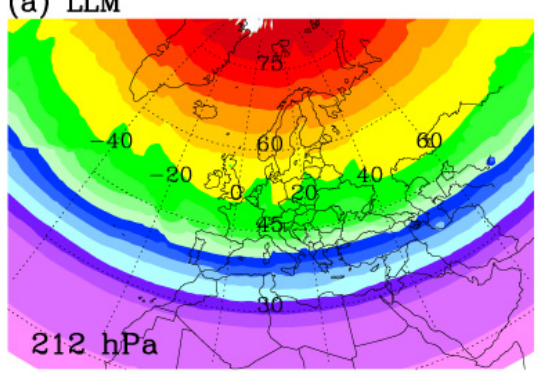

(b) TB

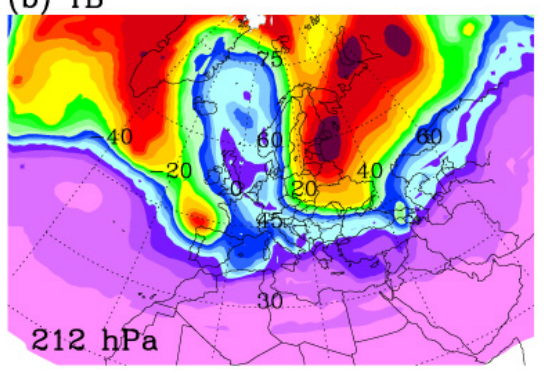

(c) GFS Potential vorticity

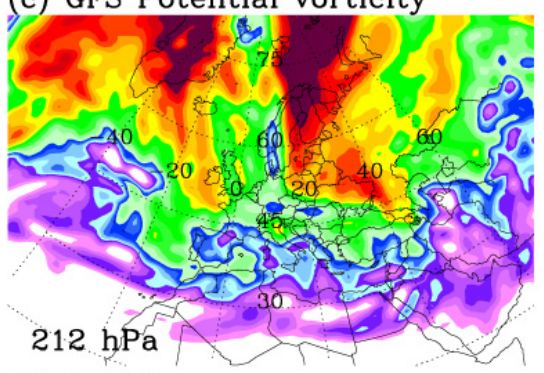

(d) GFS Tropopause

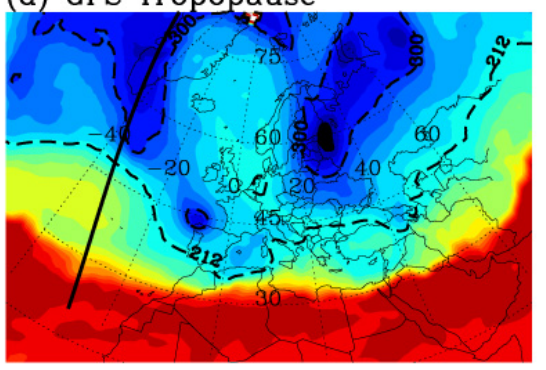

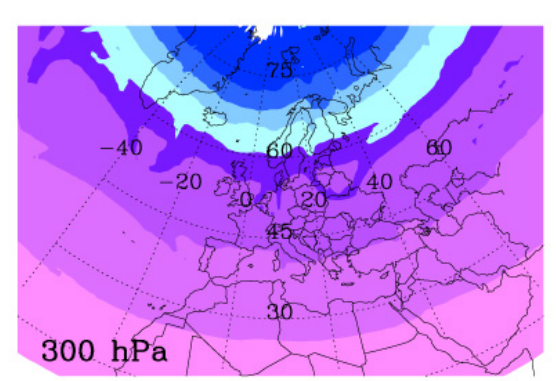
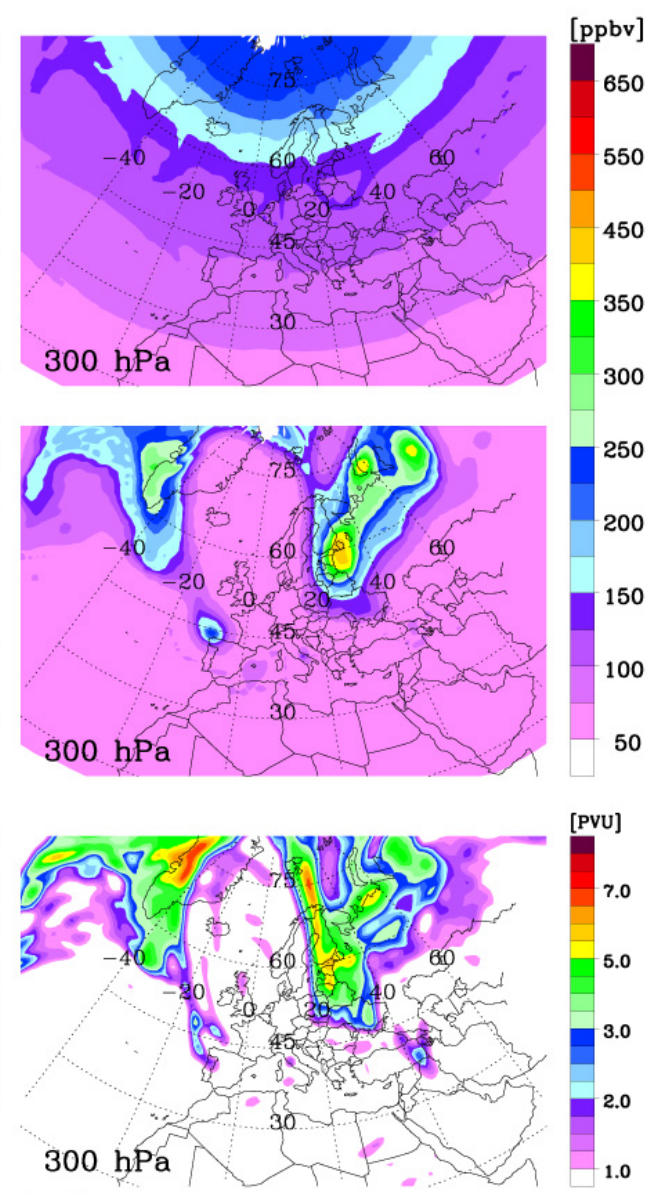

[hPa]

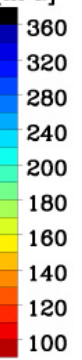

Fig. 4. Horizontal distributions of climatological mean ozone from LLM (a) and TB (b) climatologies at 212 and $300 \mathrm{hPa}$ over Europe on 30 April 2007. The associated potential vorticities (c) and tropopause heights (d) from GFS data are also presented. The solid black line in Fig. $4 \mathrm{~d}$ indicates the location of the orbit of retrievals examined in Fig. 6.

\subsection{Consistency of ozone retrievals with potential vorticity}

It is well known that ozone is highly correlated with the PV dynamical variable in the extratropical tropopause region. Previous work has presented ozone/PV ratios between 30 and 73 ppbv/PVU in the UTLS, depending on season and location, from in situ measurements (Beekmann et al., 1994; Pittman et al., 2009; Kuang et al., 2012 and references therein). In this section, we use the ozone-PV relationship as a diagnostic to evaluate the improvement of ozone retrievals in the UTLS.

Figure 7 shows scatter plots of ozone vs. collocated GFS PV values at $300 \mathrm{hPa}$, over the domain studied in Sect. 4.1, for both the a priori and the retrievals between LLM and TB climatologies. The red lines display the linear regression and correlation $(r)$ relationships. As a true reference to evaluate our retrievals, the yellow line, $31.08 \mathrm{ppbv} / \mathrm{PVU}+47.91 \mathrm{ppbv}$, describes the corresponding linear regression relationship derived using aircraft in situ measurements by Pittman et al. (2009). To be consistent 


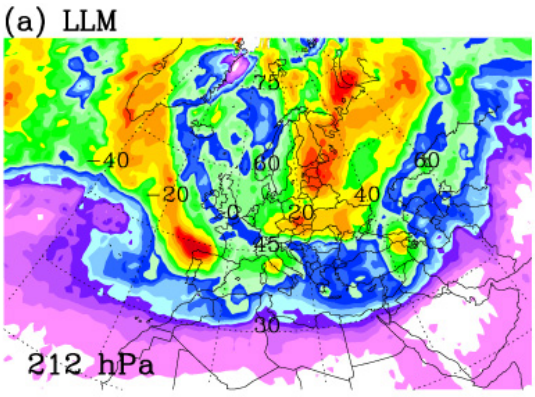

(b) TB

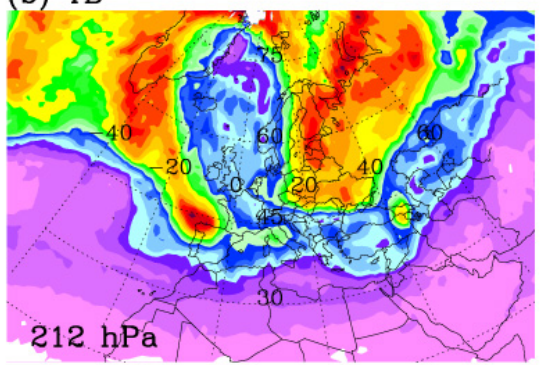

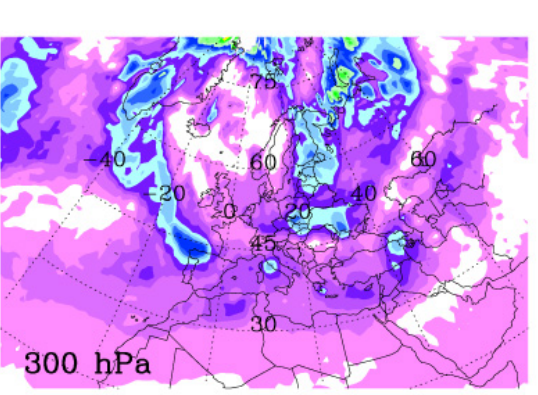
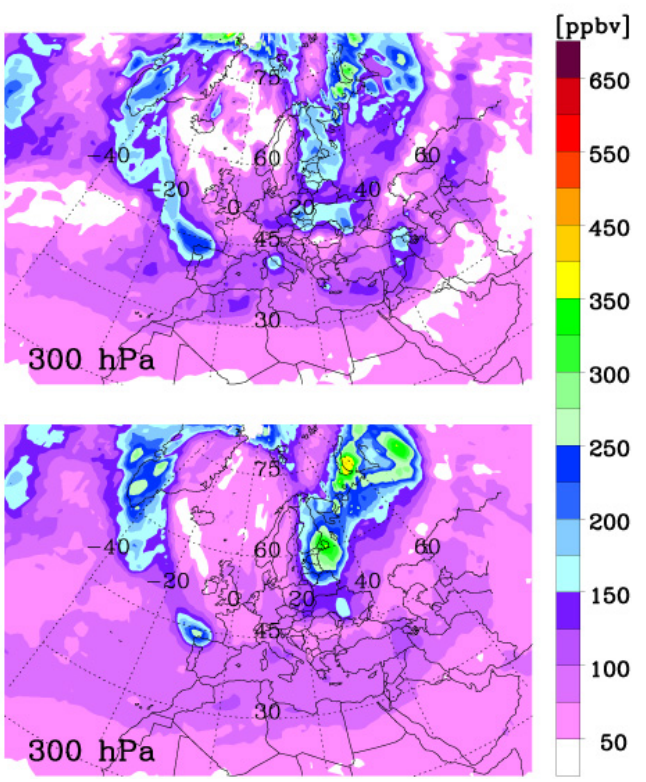

Fig. 5. Same as Fig. 4a and b, but for the OMI ozone retrievals.

with Pittman et al. (2009), we exclude points with values $\geq 5$ PVU in the linear regression. The aircraft measurements of ozone used in Pittman et al. (2009) were collected using the NCAR Gulfstream V research aircraft $(\mathrm{GV})$ during the Stratosphere-Troposphere Analyses of Regional Transport 2008 (START08) campaign (Pan et al., 2010). The flights sampled an extensive region of North America ( $25^{\circ}$ to $65^{\circ} \mathrm{N}, 86^{\circ}$ to $117^{\circ} \mathrm{W}$ ) with a focus on the UTLS up to the $120 \mathrm{hPa}$ pressure level for the period of April-June 2008. Although these in situ data are not identical in location with those selected from the OMI retrieval, the behavior of the ozone-PV relationship derived from these data is representative for the season and the dynamical range of the air mass. The comparison is a useful quantitative diagnostic for the retrievals.

As shown in Fig. 7, the ozone-PV relationships provided by the two a priori climatologies are significantly different. The LLM climatology has a very weak ozone-PV relationship (reflected in both a small $r$ value and lack of slope), which is understandable since the climatology is constructed referencing geographical latitudes and with no reference to the dynamical field. In contrast, the slope between TB a priori and $\mathrm{PV}$ values is $39.5 \mathrm{ppbv} / \mathrm{PVU}$, consistent with the climatological ozone-PV relationship ( $39 \mathrm{ppbv} / \mathrm{PVU}$ ) at $225 \mathrm{hPa}$ for spring from ozone soundings studied by Beekmann et al. (1994), while the correlation of 0.84 is much better than the $\sim 0.5$ in Beekmann et al. (1994).

The contrast of the retrievals using the two climatologies is more striking. The LLM retrieval shows an improved slope in the relationship compared to its a priori data, indicating the instrument information content of the OMI retrievals. However, the TB retrieval provides a much tighter ozone-PV relationship with the correlation improved from 0.53 to 0.75 and much smaller scatter and spread, especially at low PV ( $\sim 0-3$ PVU). As a result, the slope between TB-based retrievals and $\mathrm{PV}$ values agrees better with that derived using in situ aircraft measurements by Pittman et al. (2009); the linear slope between retrievals and PV is consistent with that from aircraft data. Additionally, the improvements of TB a priori over LLM a priori can be illustrated by comparing the number of data points included in this analysis. The number of data points in TB cases is slightly larger than in LLM cases, implying that the TB a priori helps to increase the number of successful retrievals.

\section{Comparison with ozonesonde measurements}

Ozonesonde measurements from six stations located from $67.39^{\circ} \mathrm{N}$ to $7.98^{\circ} \mathrm{S}$ during the period 2004 to 2008 were used to compare with the retrieved OMI ozone profiles using the TB, AB, and LLM climatologies. Ozonesonde stations used in this comparison are listed in Table 1, including information on ozonesonde type, the number of collocated profiles, and the data archive. The criterion to collocate OMI pixels with sonde stations is within $\pm 1.5^{\circ}$ longitude, within $\pm 1.0^{\circ}$ latitude and within $\pm 12 \mathrm{~h}$. For profile comparison, we include the analysis using the ozonesonde profiles that are downgraded vertically to the vertical resolution of OMI retrievals. Similar to Liu et al. (2006), the collocated ozonesonde profiles are integrated into partial ozone columns at OMI retrieval grids below ozone burst altitudes and then are convolved with OMI AKs. In addition to profile comparison, we evaluate partial column ozone in the UT and 
(a) A priori (LLM)

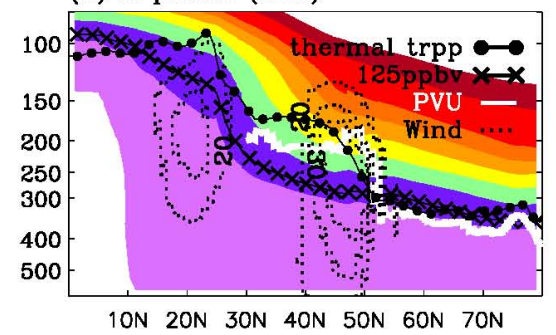

(b) OMI retrievals

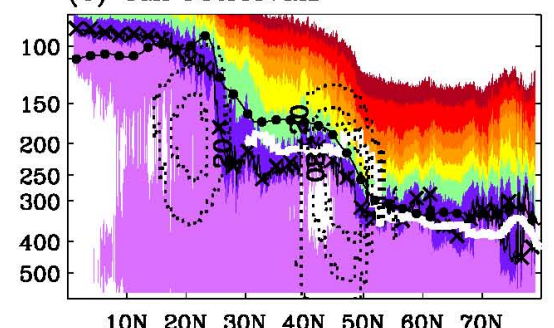

$10 \mathrm{~N} 20 \mathrm{~N} 30 \mathrm{~N} 40 \mathrm{~N} 50 \mathrm{~N} 60 \mathrm{~N} 70 \mathrm{~N}$

(c) A priori errors

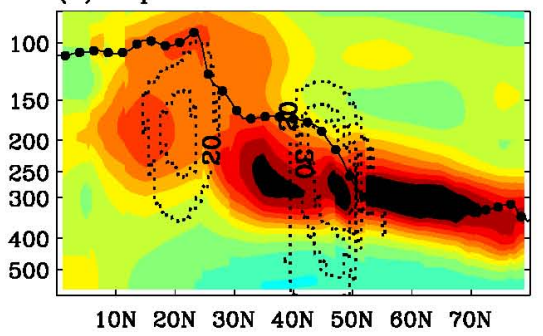

(d) Retrieval errors

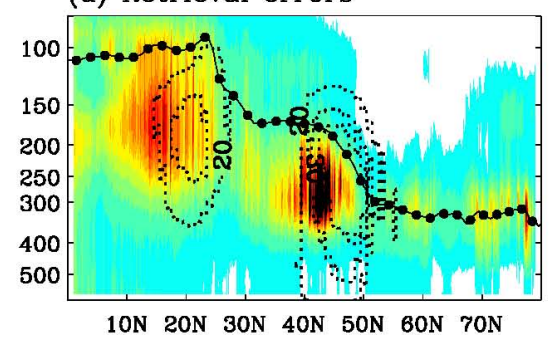

(e) A priori (TB)

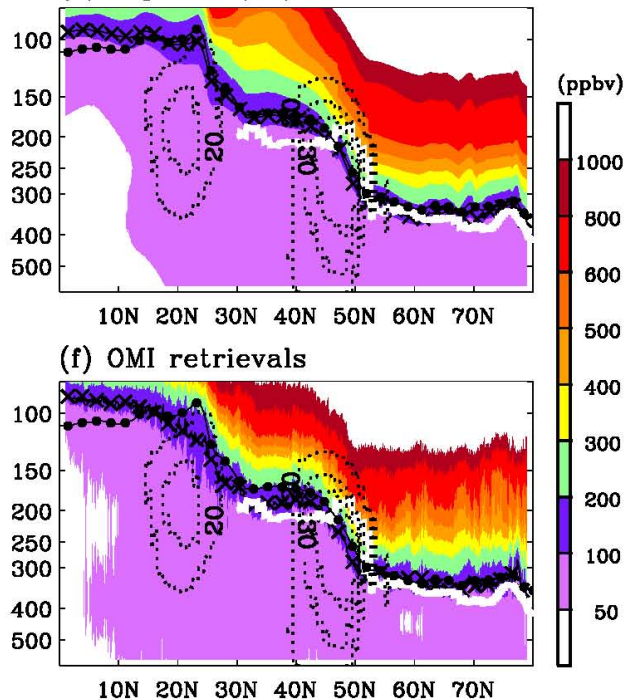

(g) A priori errors

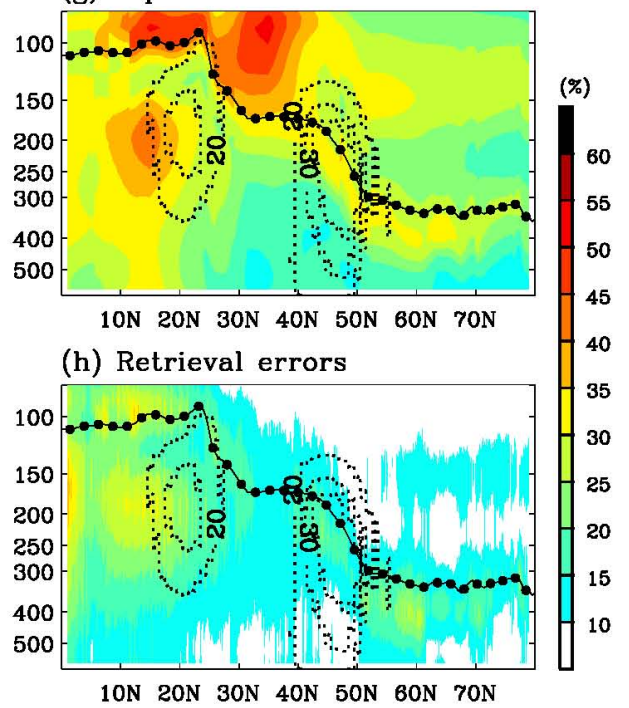

Fig. 6. Profiles of (a) a priori, (b) retrievals, (c) a priori errors, and (d) retrieval errors for 600 to $80 \mathrm{hPa}$ along the OMI overpass (solid black line) displayed in Fig. 4d. The LLM and TB climatologies are used to derive the left and right columns, respectively. This overpass is taken at the nadir position, at which the satellite viewing zenith angle is less than $4^{\circ}$, with the overpass time of 15:24 UTC near the equator. The a priori/retrieval errors are normalized to their a priori/retrievals (\%). The black dotted lines denote the wind speed of 20,30 and $40 \mathrm{~m} \mathrm{~s}^{-1}$. The $125 \mathrm{ppbv}$ value of ozone (black line with Xs), 2 PVU value (white line), and thermal tropopause (trpp) height (black line with circles) are plotted.

LS, respectively. Furthermore, we examine the ozone gradient across the tropopause. For statistical comparisons, we exclude outliers outside $3 \sigma$ of the mean difference between OMI and ozonesonde.

\subsection{Differences of ozone profiles and column ozone above and below the tropopause}

Figure 8 shows the mean biases and their standard deviations between OMI and ozonesonde profiles with and without convolution using OMI AKs at six stations. The differences between OMI retrievals and ozonesonde measurements are greatly reduced after convolution of ozonesonde profiles with OMI averaging kernels, illustrating the large smoothing errors from OMI retrievals. The use of TB climatology remarkably reduces the standard deviations of the profile differences in the UTLS at extratropical stations from Sodankylä to Wallops Island. This result is obtained independent of the convolution approach. When ozonesonde profiles convolved with OMI AKs are compared with OMI retrievals based on AB/LLM a priori, the standard deviations near the 

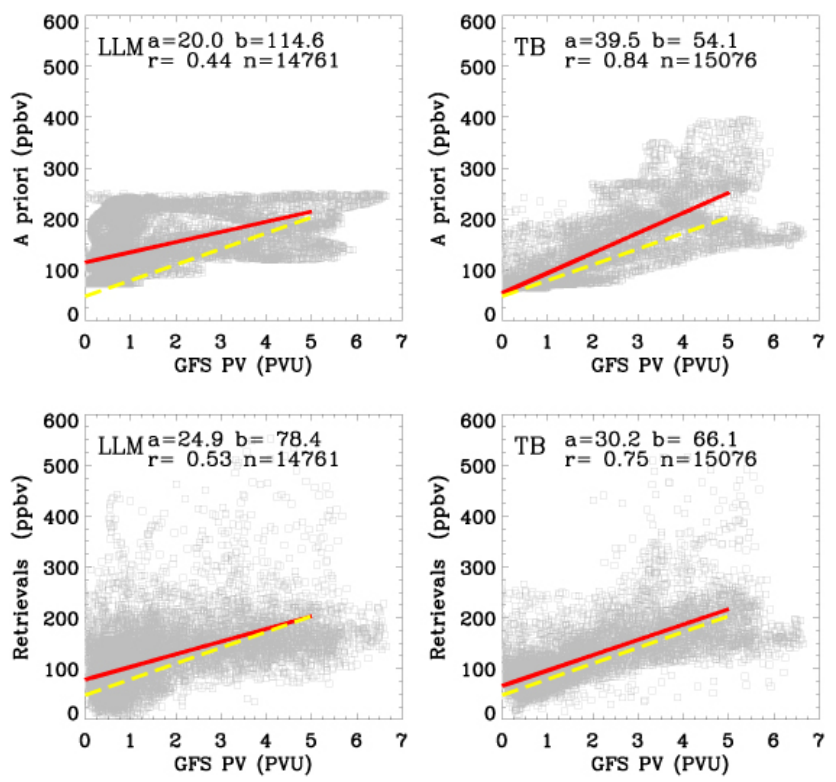

Fig. 7. The ozone-PV relationship at $300 \mathrm{hPa}$ in the spatial domain $40^{\circ} \mathrm{W}-60^{\circ} \mathrm{E}, 20-80^{\circ} \mathrm{N}$. The scatter of GFS PV values vs. LLM and $\mathrm{TB}$ a priori values is plotted in the upper panels and the scatter vs. corresponding retrieval values in the lower panels. A linear fit of PV values from 0 to 5 PVU to data is shown in red. The legends show the slope (a, ppbv/PVU) and intercept (b, ppbv) of a linear regression, with correlation coefficient $(r)$ and the number of data points $(n)$. The linear regression of PV to in situ aircraft data from the START08 experiment, $31.08 \mathrm{ppbv} / \mathrm{PVU}+47.91 \mathrm{ppbv}$, shown in Fig. 13 of Pittman et al. (2009), is shown with the dashed yellow line.

tropopause are up to $25 \%$ at Wallop Island and $\sim 50 \%$ at Sodankylä. These large standard deviations decrease by 15$25 \%$ by using the TB climatology. The use of TB climatology also improves the corresponding mean biases in the UTLS with the convolution, but increases OMI biases relative to sonde profiles above the lowest stratosphere at the Wallops Island and Hohenpeißenberg stations without convolution. At most tropical stations, from Hilo to Ascension Island, OMI retrievals with TB a priori exhibit similar profile biases and standard deviations to those with $\mathrm{AB}$ due to their similar a priori standard deviations in the troposphere and slightly larger standard deviations above the tropopause. When the ozonesonde profiles at Nairobi and Ascension Island stations are not convolved with OMI AKs, TB/AB retrievals show significantly smaller mean biases than LLM retrievals, probably because of more ozonesonde stations in the northern tropical regions and longer time periods of data for use in developing the TB/AB climatologies. In addition, the AB climatology improves agreement below the tropopause at extratropical stations, with the convolution approach, as compared to the LLM climatology.

We further examine the differences between OMI and ozonesonde profiles with convolution at Hohenpeißenberg by separating collocated profiles into four seasons as presented in Fig. 9. When AB/LLM climatology is used, the OMI retrievals show significant seasonally dependent biases, with biases especially below the tropopause ranging from $\sim 20-25 \%$ during winter to $\sim-10 \%$ during summer, and with standard deviations around the tropopause ranging from $40 \%$ during winter to $25 \%$ during summer. The use of the TB climatology not only significantly reduces the mean biases and the standard deviations in all seasons but also reduces their seasonally dependent biases. For example, the mean biases are reduced to $\sim 10 \%$ during winter and $-5 \%$ during summer, and the standard deviations in the UT/LS are reduced to $23 \%$ in winter and $15 \%$ in summer. An exception occurs $\sim 5 \mathrm{~km}$ above the tropopause, where the mean biases are sometimes slightly larger than those from the LLM/AB climatologies.

The upper panels of Fig. 10 are scatter plot comparisons of upper tropospheric column ozone (UTCO) (within $5 \mathrm{~km}$ of the tropopause) between OMI retrievals and ozonesonde observations, without the convolution approach, at Hohenpeißenberg. The UTCO comparisons between AB/LLMretrieved OMI and ozonesonde show a correlation of less than 0.36; their mean biases are $\sim 3.3 \mathrm{DU}(23 \%)$ with $\sim 4.5 \mathrm{DU}(30 \%)$ standard deviation. The use of TB climatology remarkably improves the agreement, with a correlation of 0.54 and differences of 1.6 DU $\pm 3.0 \mathrm{DU}$. The large differences in the retrievals due to the change of a priori information imply weak information from OMI measurements and the importance of a priori information in the upper troposphere. Figure 10 also evaluates the lower stratospheric column ozone (LSCO) between 0 and $3 \mathrm{~km}$ of the tropopause. As shown in Figs. 8 and 9, the improvements of retrievals above the tropopause using the TB ozone climatology are found mainly in the first few $\mathrm{km}$ above the tropopause. Thus, we only examine the LSCO within $3 \mathrm{~km}$ of the tropopause. TB retrievals show some improvement with better correlation and smaller standard deviations, although this is less significant than for the UTCO comparison. Despite the much better agreements between TB a priori and ozonesonde observations (not shown here), comparisons show similar agreements between ozonesonde and OMI retrievals with different a priori. This implies that OMI measurements contain relatively more information content for ozone above the tropopause than for below.

\subsection{Vertical gradient of ozone across the tropopause}

The ability of the OMI ozone profile retrievals to capture the ozone gradient across the tropopause region is examined in this section. The ozonesonde measurements at two extratropical stations (Hohenpeißenberg and Sodankylä) and two tropical stations (Nairobi and Ascension Island) during the period 2004 to 2008 are averaged into $1 \mathrm{~km}$ bins within $\pm 6 \mathrm{~km}$ around the tropopause. We exclude ozonesonde profiles with tropopause $>13 \mathrm{~km}$ at extratropical stations and 
(a) Sodankyla

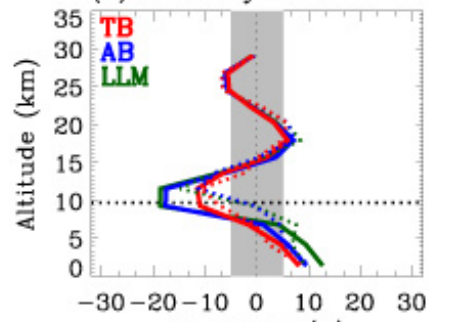

Mean Bias (\%)

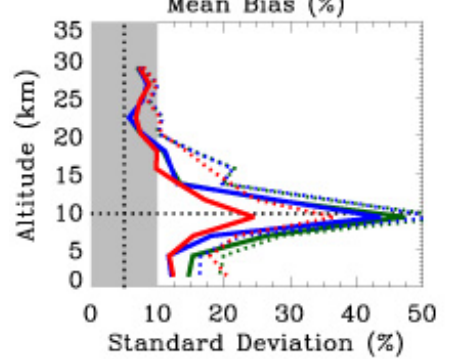

(d) Hilo
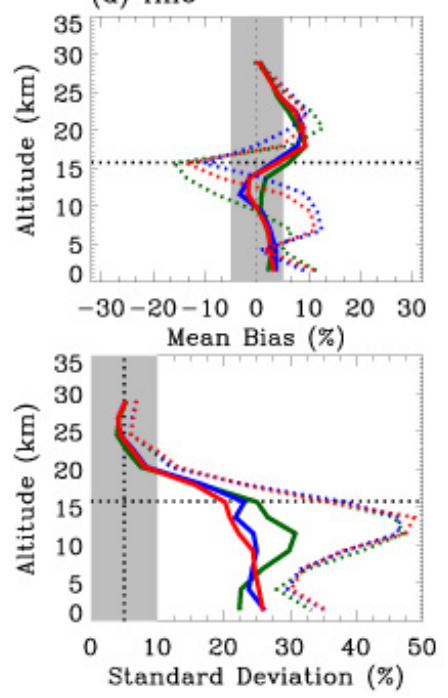

(b) HohenpeiBenberg

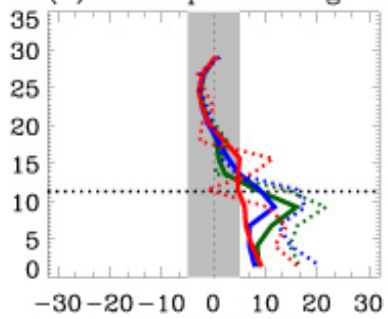

Mean Bias (\%)

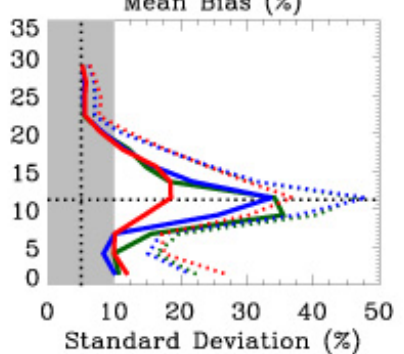

(e) Nairobi
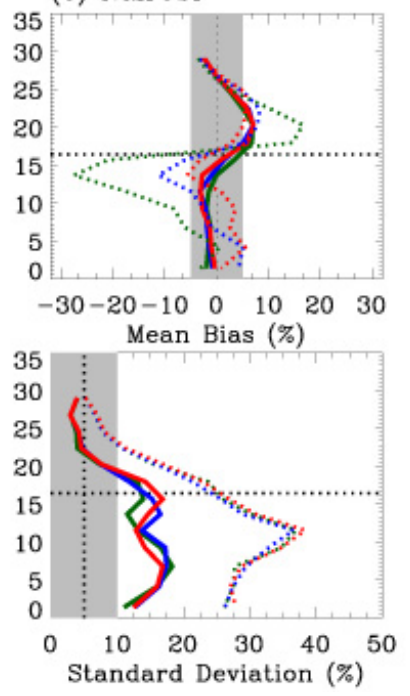

(c) Wallop Island

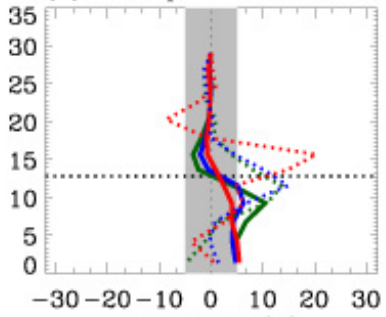

Mean Bias (\%)

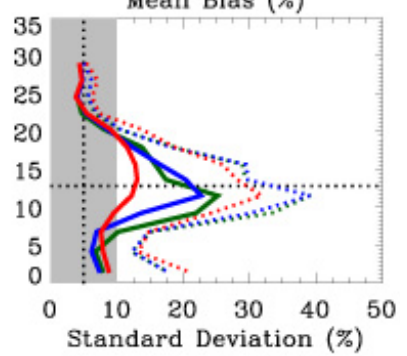

(f) Ascension Island

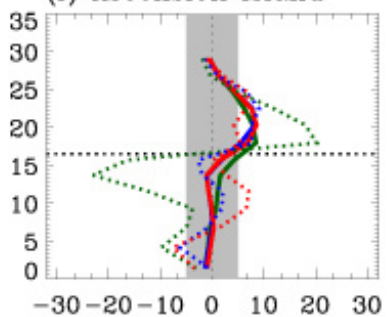

$-30-20-10 \quad 0 \quad 10 \quad 20 \quad 30$

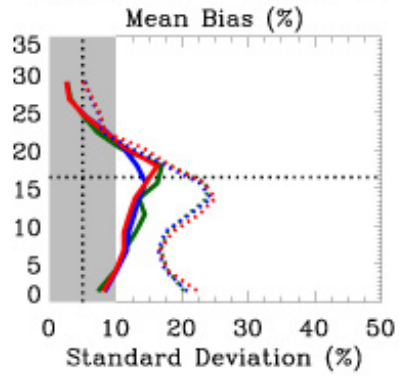

Fig. 8. Mean biases and $1 \sigma$ standard deviations of relative differences between OMI and ozonesonde profiles with (solid lines) and without (dotted lines) convolution using OMI averaging kernels from 2004 to 2008 at six stations, arranged by latitude. The relative difference is defined as $2(\mathrm{OMI}-$ sonde $) /(\mathrm{OMI}+$ sonde $) \times 100$. OMI ozone profiles are retrieved using TB (red line), AB (blue line), and LLM (green line) climatologies. The mean tropopause height is denoted with the horizontal dotted line.

with tropopause $<15 \mathrm{~km}$ at tropical stations. This process is also applied for the collocated OMI/a priori ozone profiles. To avoid the degradation of cross-tropopause gradients in this analysis, we did not convolve ozonesonde profiles with the OMI AKs. Figures 11 and 12 display the $4 \mathrm{yr}$ averages of OMI/a priori ozone profiles relative to the tropopause. The averaged ozone profiles show rapid transition within $\sim \pm 0.5 \mathrm{~km}$ around the tropopause (see the gray shaded region). Therefore, we can quantitatively estimate the sharpness of the ozone gradient within $\pm 0.5 \mathrm{~km}$ of the tropopause $\left(\mathrm{DU} \mathrm{km}^{-1}\right)$. The sharpest transitions of ozone across the tropopause are observed at extratropical ozonesonde stations, with slopes of $3.9 \mathrm{DU} \mathrm{km}^{-1}$ at
Hohenpeißenberg and 5.4 DU km${ }^{-1}$ at Sodankylä. The average of LLM/AB-retrieved ozone profiles shows significant positive biases with respect to sonde data in the upper troposphere at both stations, and shows negative biases above the tropopause at Sodankylä (where the biases are very small for the LLM/AB a priori). These lead to weaker vertical gradients of ozone at the tropopause. In addition, the ozone gradients across the tropopause in the LLM/AB retrievals actually compare worse with ozonesonde at the Sodankylä and Hohenpeißenberg than their LLM/AB a priori, likely due to too much smoothing. The improvements of TB a priori in capturing the vertical variabilities around the tropopause seen in ozonesonde measurements over other a priori are found 
(a) DJF $(n=127)$
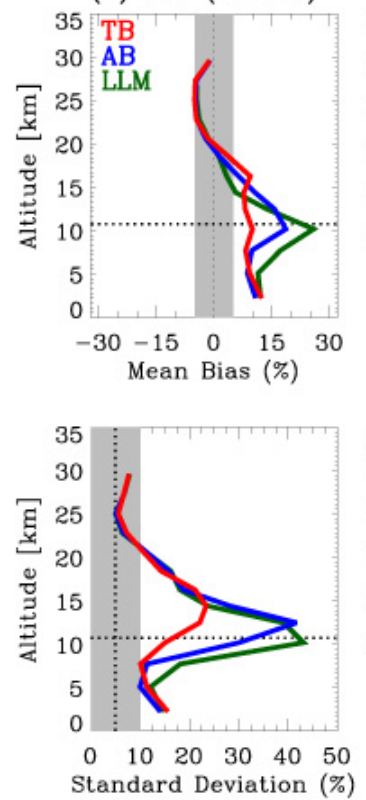

(b) MAM $(n=103)$
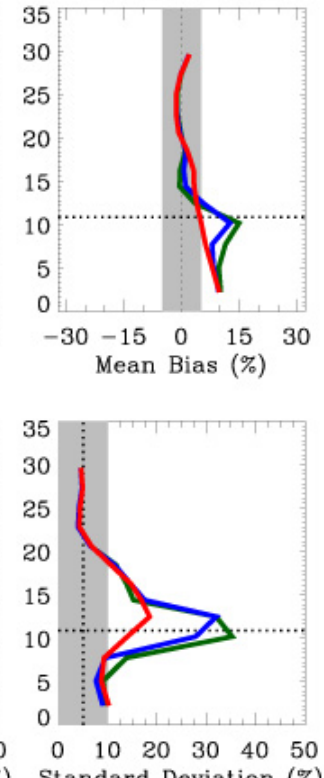

(c) JJA $(n=76)$
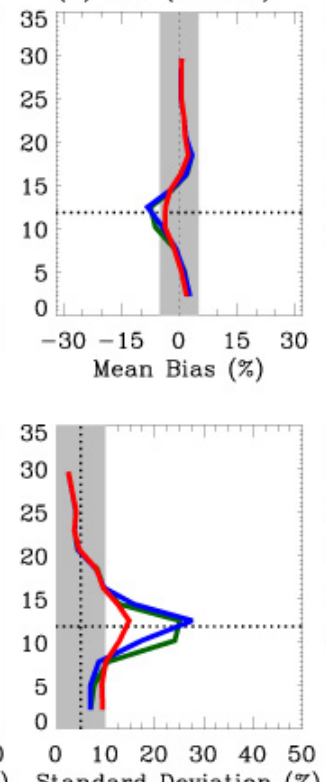

(d) SON $(n=106)$
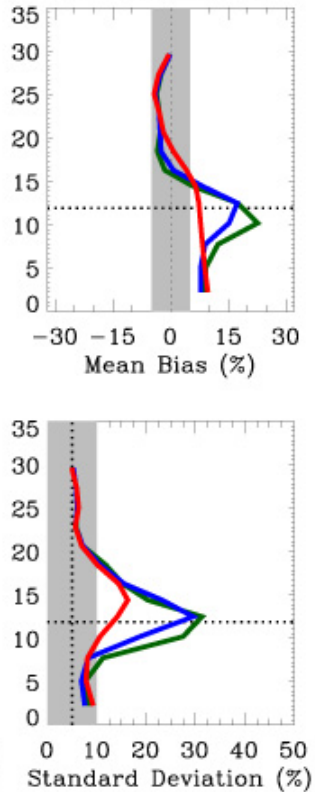

Fig. 9. Mean biases and $1 \sigma$ standard deviations between OMI and ozonesonde profiles with convolution using OMI averaging kernels at Hohenpeißenberg during (a) December/January/February (DJF), (b) March/April/May (MAM), (c) June/July/August (JJA), and (d) September/October/November (SON) from 2004 to 2008.

(a) TB
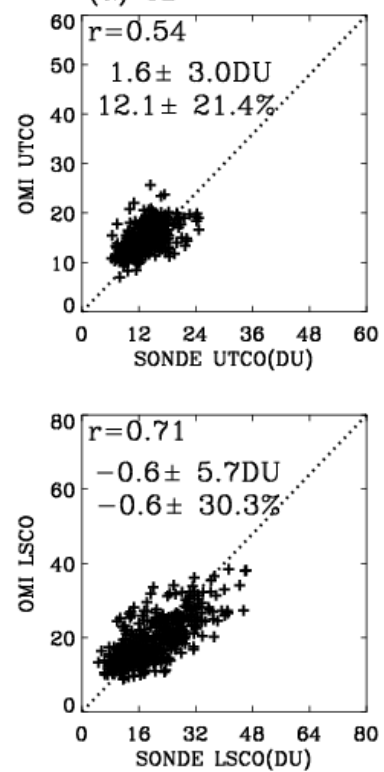

(b) $\mathrm{AB}$
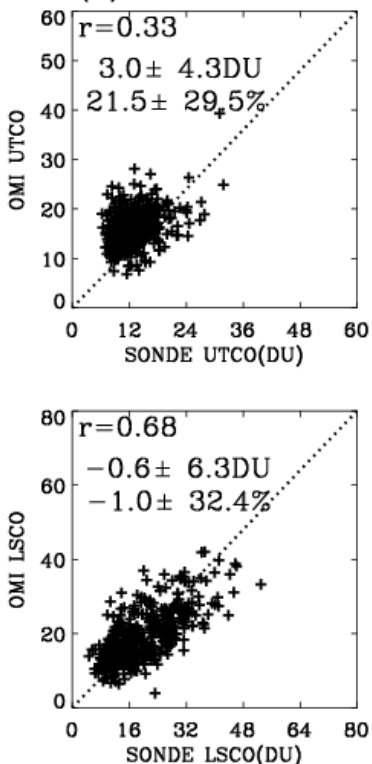

(c) LLM
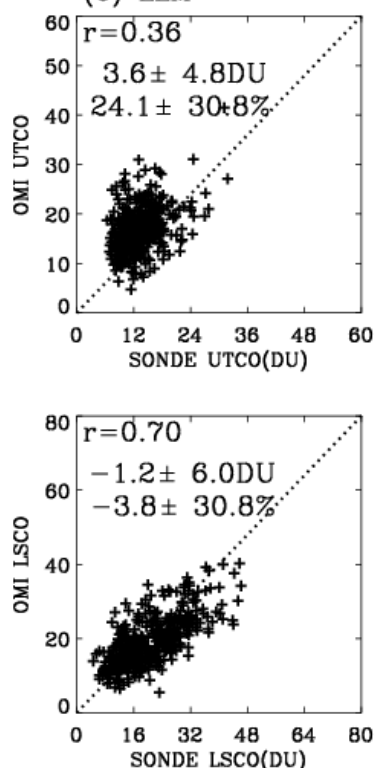

Fig. 10. Upper panels: ozonesonde upper tropospheric column ozone (UTCO) vs. OMI retrievals at Hohenpeißenberg during 2004-2008. The upper tropospheric region ranges from -5 to $0 \mathrm{~km}$ relative to the tropopause. The bottom panels are the same as the upper panels, except for showing lower stratospheric column ozone (LSCO) within $3 \mathrm{~km}$ of the tropopause. The $1: 1$ lines (dotted lines) and the correlation coefficients ( $\mathrm{r}$ ) are shown. We also give the mean biases and $1 \sigma$ standard deviations for absolute and relative differences defined as $2(\mathrm{OMI}-$ sonde $) /(\mathrm{OMI}+$ sonde $) \times 100$, respectively. Note that the ozonesonde profiles are not convolved with OMI averaging kernels. 

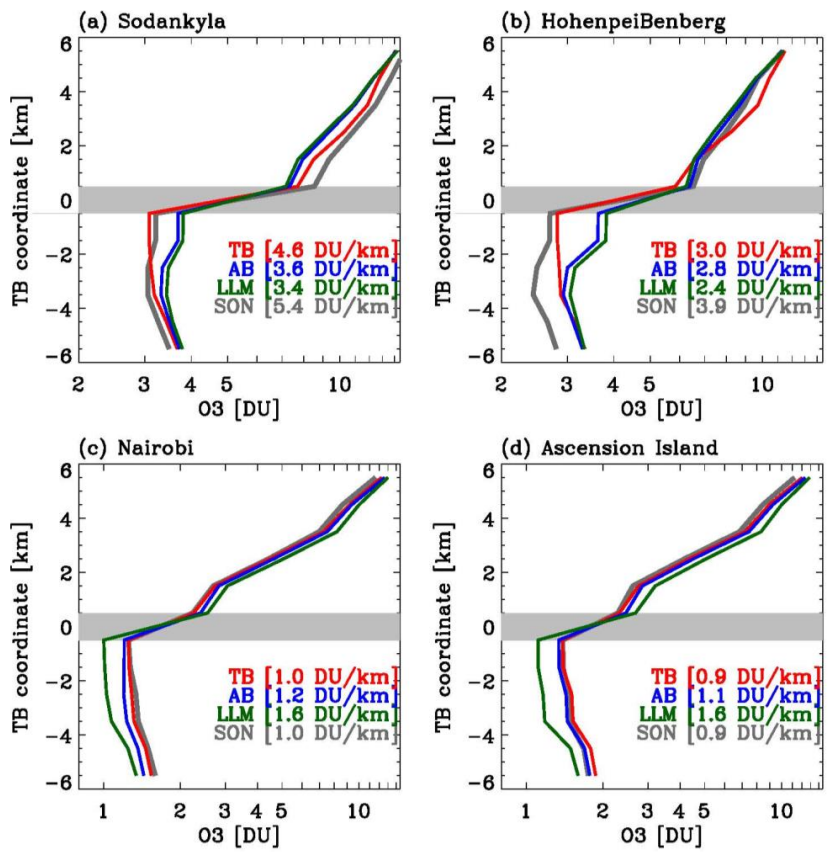

Fig. 11. Averages of ozonesonde profiles (gray lines) as a function of altitude relative to the tropopause during the period 2004-2008 at four stations, and averages of collocated OMI profiles retrieved based on TB (red lines), AB (blue lines) and LLM (green lines) climatologies. The values given in $\mathrm{DU} \mathrm{km} \mathrm{km}^{-1}$ represent the vertical gradients of ozone across the tropopause. Note that ozonesonde profiles are not convolved with OMI averaging kernels.

at most stations. One exception is that the TB a priori underestimates ozonesonde observations as well as other a priori in the lower stratosphere at Sodankylä and Hohenpeißenberg stations, and TB a priori shows worse gradients across UT/LS than other a priori at Hohenpeißenberg. Between TB a priori and retrievals, TB retrievals better capture the vertical structures in ozonesonde observations, especially at Hohenpeißenberg. At the two tropical stations, LLM a priori and retrievals significantly overestimate the ozone gradients due to large negative biases below the tropopause and positive biases above the tropopause. On the other hand, TB and AB a priori and retrievals produce ozone gradients very similar to those in the ozonesonde data, but TB a priori and retrievals show slightly better agreement than $\mathrm{AB}$ a priori/retrievals.

\section{Summary}

We examined OMI ozone profile retrievals using the monthly zonal mean ozone profile climatologies with the different vertical coordinates; tropopause-based (TB) and altitudebased $(\mathrm{AB})$ coordinates. The advantages of using the $\mathrm{TB}$ coordinates are in reducing the climatological variabilities introduced by the day-to-day dynamic variations that are reflected in tropopause height variations and improving the sharpness of the ozone gradient across the tropopause.
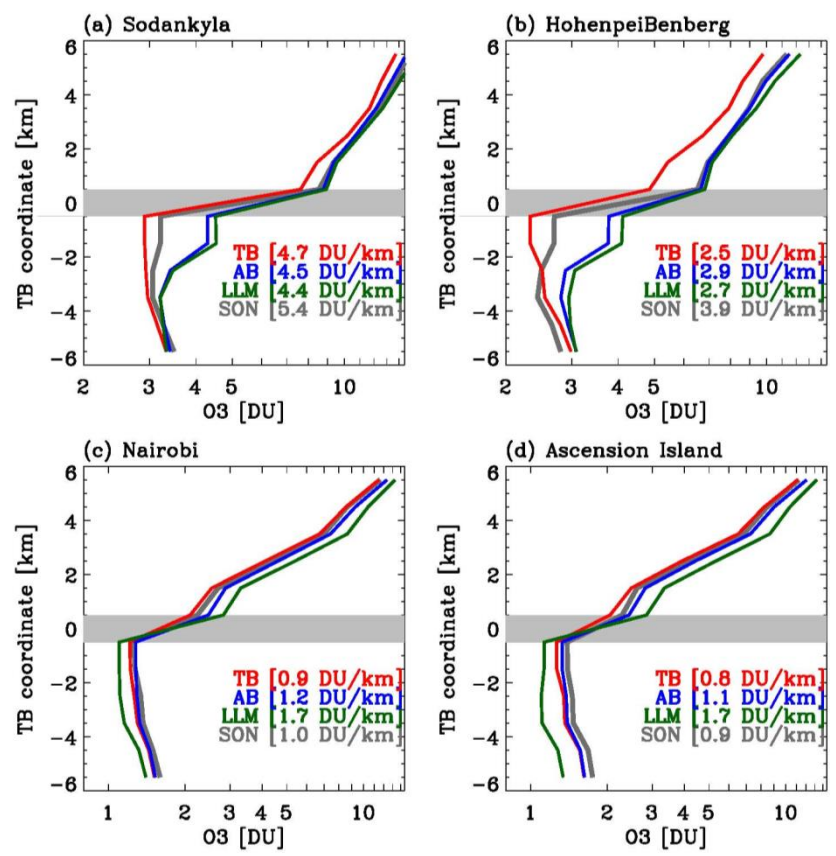

Fig. 12. Same as Fig. 11, but for a priori profiles used in OMI retrievals.

However, the advantages are limited to a few $\mathrm{km}$ around the extratropical tropopause. Therefore, we improved the TB ozone climatology in several different ways from the previous study by Wei2010. (1) The TB coordinate is transformed from the $\mathrm{AB}$ coordinate by applying a variable shifting offset in order to confine the use of the TB coordinate to within $\pm 5 \mathrm{~km}$ around the tropopause. (2) Ozonesonde profiles are separated into tropical and extratropical regimes, with a threshold value of $14 \mathrm{~km}$ tropopause height, to reduce the climatological variabilities in subtropical latitude bands and enhance the characteristics of both tropical and extratropical air masses. We derived tropical and extratropical TB climatologies. The tropical (extratropical) TB climatology is used to define a priori at tropopause height $\geq 15 \mathrm{~km}$ $(\leq 13 \mathrm{~km})$. At the transition zone between 13 and $15 \mathrm{~km}$, the a priori is weighted linearly from $100 \%$ extratropical TB profile at $13 \mathrm{~km}$ to $100 \%$ tropical TB profile at $15 \mathrm{~km}$. (3) The TB/AB profile is linearly merged with the LLM profile from $5-10 \mathrm{~km}$ above the tropopause, $100 \% \mathrm{~TB} / \mathrm{AB}$ at $5 \mathrm{~km}$ and $100 \%$ LLM at $10 \mathrm{~km}$, and is replaced by the LLM profile from $10 \mathrm{~km}$ above the tropopause upward. The TB climatology can better represent the daily ozone variability horizontally and vertically.

We also evaluated ozone profile retrievals against meteorological data and ozonesonde observations during the period of 2004 to 2008 to show how much OMI retrievals are improved by using our new TB climatology. The improvements include: (1) the large-scale ozone variability associated with the strong PV gradients is well represented in climatological ozone fields (Sect. 4.1); (2) the ozone tropopause 
derived from retrievals better tracks other tropopause definitions including the thermal tropopause and the PV-based tropopause (Sect. 4.1); (3) the statistical relationship between retrievals and PV values is enhanced (Sect. 4.2); (4) mean biases and standard deviations between OMI and ozonesonde data are significantly reduced in the extratropical troposphere and lowermost stratosphere (Sect. 5.1); and (5) ozone gradients across the tropopause found in sonde data are better reproduced in the OMI retrievals in both tropical and extratropical regions (Sect. 5.2). These improvements demonstrate that the TB climatology provides better constraints to the retrieval of ozone profiles in the UTLS from BUV radiances. The improved retrievals (with global coverage) around the tropopause will enhance the use of BUV retrievals for UTLS research in the global perspective.

Acknowledgements. Research at Pusan National University by J. Bak and J. H. Kim is funded by the Eco Innovation Program of KEITI (ARQ201204015), Korea. Research at the Smithsonian Astrophysical Observatory (SAO) by X. Liu and K. Chance, as well as by J. Bak during her 6-month visit to the SAO is supported by NASA and the Smithsonian Institution. We acknowledge the WOUDC, SHADOZ and NOAA/ESRL for providing ozonesonde data, OMI science team for providing OMI level $1 \mathrm{~b}$ data. The NCEP GFS data for this study are from the Research Data Archive (RDA), which is maintained by the Computational and Information Systems Laboratory (CISL) at the National Center for Atmospheric Research (NCAR); the original data are available from the RDA (http://rda.ucar.edu) in dataset number ds083.2.

Edited by: M. Van Roozendael

\section{References}

Beekmann, M., Ancellet, G., and Mégie, G.: Climatology of tropospheric ozone in southern Europe and its relation to potential vorticity, J. Geophys. Res., 99, 12841-12853, doi:10.1029/94JD00228, 1994.

Bhartia, P. K., McPeters, R. D., Mateer, C. L., Flynn, L. E., and Wellemeyer, C.: Algorithm for the estimation of vertical ozone profiles from the backscattered ultraviolet technique, J. Geophys. Res., 101, 18793-18806, doi:10.1029/96JD01165, 1996.

Birner, T.: Fine-scale structure of the extratropical tropopause region, J. Geophys. Res., 111, D04104, doi:10.1029/2005JD006301, 2006.

Birner, T.: Recent widening of the tropical belt from global tropopause statistics: Sensitivities, J. Geophys. Res., 115, D23109, doi:10.1029/2010JD014664, 2010.

Chance, K. V., Burrows, J. P., Perner, D., and Schneider, W.: Satellite measurements of atmospheric ozone profiles, including tropospheric ozone, from ultraviolet/visible measurements in the nadir geometry: a potential method to retrieve tropospheric ozone, J. Quant. Spectrosc. Ra., 57, 467-476, 1997.
Considine, D. B., Logan, J. A., and Olsen, M. A.: Evaluation of near-tropopause ozone distributions in the Global Modeling Initiative combined stratosphere/troposphere model with ozonesonde data, Atmos. Chem. Phys., 8, 2365-2385, doi:10.5194/acp-8-2365-2008, 2008.

de Forster, P. M. F. and Shine, K. P.: Radiative forcing and temperature trends from stratospheric ozone changes, J. Geophys. Res., 102, 10841-10855, doi:10.1029/96JD03510, 1997.

de Forster, P. M. F. and Tourpali, K.: Effect of tropopause height changes on the calculation of ozone trends and their radiative forcing, J. Geophys. Res., 106, 12241-12252, doi:10.1029/2000JD900813, 2001.

ESA - European Space Agency: The GOME Users Manual, edited by: Bednarz, F., ESA Publication SP-1182, ESA Publications Division, ESTEC, Noordwijk, the Netherlands, 1995.

Hegglin, M. I., Boone, C. D., Manney, G. L., Shepherd, T. G., Walker, K. A., Bernath, P. F., Daffer, W. H., Hoor, P., and Schiller, C.: Validation of ACE-FTS satellite data in the upper troposphere/lower stratosphere (UTLS) using non-coincident measurements, Atmos. Chem. Phys., 8, 1483-1499, doi:10.5194/acp8-1483-2008, 2008.

Hegglin, M. I., Boone, C. D., Manney, G. L., and Walker, K. A.: A global view of the extratropical tropopause transition layer from Atmospheric Chemistry Experiment Fourier Transform Spectrometer $\mathrm{O}_{3}, \mathrm{H}_{2} \mathrm{O}$, and CO, J. Geophys. Res., 114, D00B11, doi:10.1029/2008JD009984, 2009.

Hoinka, K. P.: The tropopause: discovery, definition and demarcation, Meteorol. Z., 6, 281-303, 1997.

Holton, J. R., Haynes, P. H., McIntyre, M. E., Douglass, A. R., Rood, R. B., and Pfister, L.: Stratosphere-troposphere exchange, Rev. Geophys., 33, 403-439, doi:10.1029/95RG02097, 1995.

Homeyer, C. R., Bowman, K. P., and Pan, L. L.: Extratropical tropopause transition layer characteristics from highresolution sounding data, J. Geophys. Res., 115, D13108, doi:10.1029/2009JD013664, 2010.

Kuang, S., Newchurch, M. J., Burris, J., Wang, L., Knupp, K., and Huang, G.: Stratosphere-to-troposphere transport revealed by ground-based lidar and ozonesonde at a midlatitude site, J. Geophys. Res., 117, D18305, doi:10.1029/2012JD017695, 2012.

Kunz, A., Pan, L. L., Konopka, P., Kinnison, D. E., and Tilmes, S.: Chemical and dynamical discontinuity at the extratropical tropopause based on START08 and WACCM analyses, J. Geophys. Res., 116, D24302, doi:10.1029/2011JD016686, 2011.

Langford, A. O.: Stratosphere-troposphere exchange at the subtropical jet: Contribution to the tropospheric ozone budget at midlatitudes, Geophys. Res. Lett., 26, 2449-2452, doi:10.1029/1999GL900556, 1999.

Levelt, P. F., van den Oord, G. H. J., Dobber, M. R., Malkki, A., Visser, H., de Vries, J., Stammes, P., Lundell, J. O. V., and Saari, H.: The Ozone Monitoring Instrument, IEEE T. Geosci. Remote, 44, 1093-1101, doi:10.1109/TGRS.2006.872333, 2006.

Liu, X., Chance, K., Sioris, C. E., Spurr, R. J. D., Kurosu, T. P., Martin, R. V., and Newchurch, M. J.: Ozone profile and tropospheric ozone retrievals from Global Ozone Monitoring Experiment: algorithm description and validation, J. Geophys. Res., 110, D20307, doi:10.1029/2005JD006240, 2005. 
Liu, X., Chance, K., Sioris, C. E., Kurosu, T. P., and Newchurch, M. J.: Intercomparison of GOME, ozonesonde, and SAGE-II measurements of ozone: Demonstration of the need to homogenize available ozonesonde datasets, J. Geophys. Res., 101, D114305, doi:10.1029/2005JD006718, 2006.

Liu, X., Bhartia, P. K., Chance, K., Spurr, R. J. D., and Kurosu, T. P.: Ozone profile retrievals from the Ozone Monitoring Instrument, Atmos. Chem. Phys., 10, 2521-2537, doi:10.5194/acp-10-25212010, 2010a.

Liu, X., Bhartia, P. K., Chance, K., Froidevaux, L., Spurr, R. J. D., and Kurosu, T. P.: Validation of Ozone Monitoring Instrument (OMI) ozone profiles and stratospheric ozone columns with Microwave Limb Sounder (MLS) measurements, Atmos. Chem. Phys., 10, 2539-2549, doi:10.5194/acp-10-2539-2010, 2010b.

Logan, J. A.: An analysis of ozonesonde data for the troposphere: Recommendations for testing 3-D models and development of a gridded climatology for tropospheric ozone, J. Geophys. Res., 104, 16115-16149, doi:10.1029/1998JD100096, 1999.

McPeters, R. D., Heath, D. F., and Bhartia, P. K.: Average Ozone Profiles for 1979 From the NIMBUS 7 SBUV instrument, J. Geophys. Res., 89, 5199-5214, doi:10.1029/JD089iD04p05199, 1984.

McPeters, R. D., Labow, G. J., and Logan, J. A.: Ozone climatological profiles for satellite retrieval algorithms, J. Geophys. Res., 112, D05308, doi:10.1029/2005JD006823, 2007.

Meijer, Y. J., Swart, D. P. J., Baier, F., Bhartia, P. K., Bodeker, G. E., Casadio, S., Chance, K., Del Frate, F., Erbertseder, T., Felder, M. D., Flynn, L. E., Godin-Beekmann, S., Hansen, G., Hasekamp, O. P., Kaifel, A., Kelder, H. M., Kerridge, B. J., Lambert, J. C., Landgraf, J., Latter, B., Liu, X., McDermid, I. S., Pachepsky, Y., Rozanov, V., Siddans, R., Tellmann, S., van der A, R. J., van Oss, R. F., Weber, M., and Zehner, C.: Evaluation of Global Ozone Monitoring Experiment (GOME) ozone profiles from nine different algorithms, J. Geophys. Res., 111, D21306, doi:10.1029/2005JD006778, 2006.

Pan, L. L. and Munchak, L. A.: Relationship of cloud top to the tropopause and jet structure from CALIPSO data, J. Geophys. Res., 116, D12201, doi:10.1029/2010JD015462, 2011.

Pan, L. L., Randel, W. J., Gary, B. L., Mahoney, M. J., and Hintsa, E. J.: Definitions and sharpness of the extratropical tropopause: A trace gas perspective, J. Geophys. Res., 109, D23103, doi:10.1029/2004JD004982, 2004.

Pan, L. L., Wei, J. C., Kinnison, D. E., Garcia, R. R., Wuebbles, D. J., and Brasseur, G. P.: A set of diagnostics for evaluating chemistry-climate models in the extratropical tropopause region, J. Geophys. Res., 112, D09316, doi:10.1029/2006JD007792, 2007.
Pittman, J. V., Pan, L. L., Wei, J. C., Irion, F. W., Liu, X., Maddy, E. S., Barnet, C. D., Chance, K., and Gao, R.-S.: Evaluation of AIRS, IASI, and OMI ozone profile retrievals in the extratropical tropopause region using in situ aircraft measurements, J. Geophys. Res., 114, D24109, doi:10.1029/2009JD012493, 2009.

Randel, W. J., Seidel, D. J., and Pan, L. L.: Observational characteristics of double tropopauses, J. Geophys. Res., 112, D07309, doi:10.1029/2006JD007904, 2007.

Rodgers, C. D.: Inverse methods for Atmospheric Sounding: Theory and Practice, World Scientific Publishing, Singapore, 2000.

Santer, B. D., Wigley, T. M. L., Simmons, A. J., Kàllberg, P. W., Kelly, G. A., Uppala, S. M., Ammann, C., Boyle, J. S., Brüggemann, W., Doutriaux, C., Fiorino, M., Mears, C., Meehl, G. A., Sausen, R., Taylor, K. E., Washington, W. M., Wehner, M. F., and Wentz, F. J.: Identification of anthropogenic climate change using a second-generation reanalysis, J. Geophys. Res., 109, D21104, doi:10.1029/2004JD005075, 2004.

Steinbrecht, W., Claude, H., Köhler, U., and Hoinka, K. P.: Correlations between tropopause height and total ozone: Implications for long-term changes, J. Geophys. Res., 103, 19183-19192, doi:10.1029/98JD01929, 1998.

Tilmes, S., Pan, L. L., Hoor, P., Atlas, E., Avery, M. A., Campos, T., Christensen, L. E., Diskin, G. S., Gao, R.-S., Herman, R. L., Hintsa, E. J., Loewenstein, M., Lopez, J., Paige, M. E., Pittman, J. V., Podolske, J. R., Proffitt, M. R., Sachse, G. W., Schiller, C., Schlager, H., Smith, J., Spelten, N., Webster, C., Weinheimer, A., and Zondlo, M. A.,: An aircraft-based upper troposphere lower stratosphere $\mathrm{O}_{3}, \mathrm{CO}$, and $\mathrm{H}_{2} \mathrm{O}$ climatology for the Northern Hemisphere, J. Geophys. Res., 115, D14303, doi:10.1029/2009JD012731, 2010.

Varotsos, C., Cartalis, C., Vlamakis, A., Tzanis, C., and Keramitsoglou, I.: The Long-Term Coupling between Column Ozone and Tropopause Properties, J. Climate, 17, 3843-3854, doi:10.1175/1520-0442(2004)017<3843:TLCBCO > 2.0.CO;2, 2004.

Wei, J. C., Pan, L. L., Maddy, E., Pittman, J. V., Divarkarla, M., Xiong, X., and Barnet, C.: Ozone profile retrieval from an advanced infrared sounder: Experiments with tropopause-based climatology and optimal estimation approach, J. Atmos. Ocean. Tech., 27, 1123-1139, doi:10.1175/2010JTECHA1384.1, 2010.

WMO - World Meteorological Organization: Meteorology - A three-dimensional science: Second session of the commission for aerology, World Meteorol. Organ. Bull., 4, 134-138, 1957. 